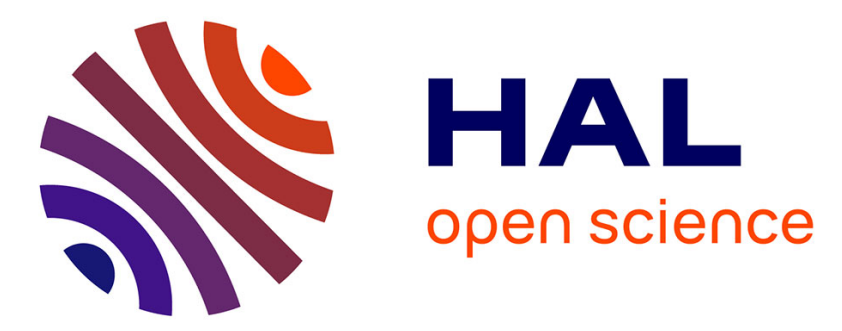

\title{
Reevaluation of the Late Pleistocene Slip Rate of the Haiyuan Fault Near Songshan, Gansu Province, China
}

Wenqian Yao, Jing Liu-zeng, M. Oskin, Wei Wang, Zhanfei Li, Veronica Prush, Jinyu Zhang, Yanxiu Shao, Zhaode Yuan, Yann Klinger

\section{- To cite this version:}

Wenqian Yao, Jing Liu-zeng, M. Oskin, Wei Wang, Zhanfei Li, et al.. Reevaluation of the Late Pleistocene Slip Rate of the Haiyuan Fault Near Songshan, Gansu Province, China. Journal of Geophysical Research : Solid Earth, 2019, 124 (5), pp.5217-5240. 10.1029/2018JB016907 . hal-02324469

\section{HAL Id: hal-02324469 \\ https://hal.science/hal-02324469}

Submitted on 22 Mar 2021

HAL is a multi-disciplinary open access archive for the deposit and dissemination of scientific research documents, whether they are published or not. The documents may come from teaching and research institutions in France or abroad, or from public or private research centers.
L'archive ouverte pluridisciplinaire HAL, est destinée au dépôt et à la diffusion de documents scientifiques de niveau recherche, publiés ou non, émanant des établissements d'enseignement et de recherche français ou étrangers, des laboratoires publics ou privés. 


\author{
RESEARCH ARTICLE \\ 10.1029/2018JB016907 \\ Key Points: \\ - Slip rate of the Haiyuan fault near \\ longitude $37^{\circ}$ is determined to be \\ between 5.0 and $8.9 \mathrm{~mm} /$ year over \\ the last $\sim 26 \mathrm{ka}$ \\ - Lower bound in geologic slip rate is \\ similar to geodetic strain rate
}

Supporting Information:

- Supporting Information S1

- Data Set S1

Correspondence to:

W. Yao and J. Liu-Zeng,

wenqian_08@163.com;

liu-zeng@ies.ac.cn

Citation:

Yao, W., Liu-Zeng, J., Oskin, M. E., Wang, W., Li, Z., Prush, V., et al. (2019) Reevaluation of the Late Pleistocene slip rate of the Haiyuan fault near Songshan, Gansu province, China. Journal of Geophysical Research: Solid Earth, 124, 5217-5240. https://doi.org/ 10.1029/2018JB016907

Received 18 OCT 2018 Accepted 21 APR 2019

Accepted article online 29 APR 2019

Published online 29 MAY 2019

(C)2019. American Geophysical Union. All Rights Reserved.

\section{Reevaluation of the Late Pleistocene Slip Rate of the Haiyuan Fault Near Songshan, Gansu Province, China}

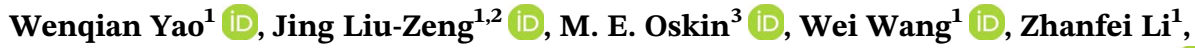 \\ Veronica Prush ${ }^{3}$, Jinyu Zhang ${ }^{1}$, Yanxiu Shao ${ }^{4}$, Zhaode Yuan ${ }^{1}$, and Yann Klinger ${ }^{5}$ (iD \\ ${ }^{1}$ State Key Laboratory of Earthquake Dynamics, Institute of Geology, China Earthquake Administration, Beijing, China, \\ ${ }^{2}$ Institute of Surface-Earth System Science, Tianjin University, Tianjin, China, ${ }^{3}$ Department of Earth and Planetary \\ Sciences, University of California, Davis, CA, USA, ${ }^{4}$ Lanzhou Institute of Seismology, China Earthquake Administration, \\ Lanzhou, China, ${ }^{5}$ Institut de Physique du Globe de Paris, Sorbonne Paris Cité, Université Paris Diderot, UMR 7154 CNRS, \\ Paris, France
}

\begin{abstract}
Well-constrained fault slip rates are important for understanding strain partitioning within a fault system and the associated seismic hazard. The Haiyuan fault is a significant active strike-slip fault in the northeast margin of the Tibetan Plateau with ongoing controversy over its late Pleistocene slip rate. Previous work by Lasserre et al. (1999) suggested a slip rate of $12 \pm 4 \mathrm{~mm} /$ year, which is higher than recent geodetically determined rates on adjacent fault sections. We reanalyze and reevaluate the slip rates benefiting from new high-resolution airborne Light Detection and Ranging data at their two sites, located north of the Songshan village. Based on this data, we revise field-mapped offset constraints. At the Majia Wan site, we document a sinistral displacement of $130 \pm 10 \mathrm{~m}$ of the crest and $93 \pm 15 \mathrm{~m}$ of the base of T1/T2 terrace riser, respectively. At the Xuanma Wan site, the offset of T4/T1' terrace riser is updated to be $68^{+3} /{ }_{-10} \mathrm{~m}$. Combining new geochronology dates, we assess the abandonment age of T2 as $26.0 \pm 4.5 \mathrm{ka}$ and $\mathrm{T} 1$ as $9,445 \pm 30$ year. These data suggest a slip rate between $5.0^{+1.5} /{ }_{-1.1}$ and $8.9^{+0.5} /{ }_{-1.3} \mathrm{~mm} /$ year since $\sim 26 \mathrm{ka}$, based on the upper terrace and lower terrace reconstruction, respectively. Our reevaluation supports that apparent slip rate discrepancies in northern Tibet possibly share a systematic bias due to the use of lower-terrace reconstruction to interpret the age of offset.
\end{abstract}

\section{Introduction}

The slip rate of a fault is a basic and important quantity in understanding the kinematic and strain partitioning in a complex fault system. It is also one of the key parameters in seismic hazard evaluation. Spatial and temporal variation of slip rate along faults shed light on their mechanical behavior (Chevalier et al., 2005; Chéry \& Vernant, 2006; Frankel et al., 2007; Friedrich et al., 2003; Kirby et al., 2007; Rittase et al., 2014). Determining the slip rate of the significant active strike-slip faults is also important to test end-member kinematic models for deformation of the Tibet plateau. For instance, one class of models emphasizes localized deformation and relatively fast slip rates along large strike-slip faults that bound lithosphere-scale blocks (Avouac \& Tapponnier, 1993; Peltzer \& Saucier, 1996; Peltzer \& Tapponnier, 1988; Tapponnier et al., 1986, 2001; Thatcher, 2007). The other class of models advocates continuous deformation within the plateau, minimizing the role of strike-slip faulting in accommodating continental deformation (England \& Houseman, 1986; England \& McKenzie, 1982; England \& Molnar, 2005; Molnar \& Tapponnier, 1975; Royden et al., 1997, 2008). Thus, intensive efforts have been devoted to determining the Quaternary slip rates along these major faults and to refine associated uncertainties (e.g., Bai et al., 2018; Chevalier et al., 2016; Cowgill, 2007; Cowgill et al., 2009; Gold et al., 2011; Jiang et al., 2017; Kirby et al., 2007; Lasserre et al., 1999, 2002; Mériaux et al., 2004, 2005; van der Woerd et al., 1998, 2002, 2006; Zhang et al., 2007).

It is not easy to establish a well-constrained geologic slip rate of an active strike-slip fault, despite that determining slip rate is simple in principle. It must meet requirements of two components simultaneously: (1) identifying clear offset piercing lines that record the accumulation of slip and (2) tight constraints on the age of cumulative slip, through dating relevant offset landforms with suitable geochronological techniques. Finding offset piercing lines is relatively easy; erosional features, such as deflected channels or offset terrace 
risers, often offer excellent preserved offset markers. However, determining the time when offset starts to accumulate is not straightforward when the offset feature is formed by erosion. It is common to use the ages of constructional landforms as a surrogate, which provides bounds rather than the true age of the offset feature. For instance, the abandonment age of alluvial fan provides the maximum age of (thus could be older than) the offset of channels that developed into the fan. Similarly, the initiation of the offset of a terrace riser can be any time between the abandonment age of the upper terrace (the lower bound) and that of the lower terrace (the upper bound). Assuming the upper terrace or lower terrace age in offset accumulation reconstruction will yield different estimates of slip rate at the same site (Cowgill, 2007; Zhang et al., 2007).

Prior slip rate studies along the Haiyuan fault, one of the most conspicuous strike-slip faults in the Tibetan Plateau, have yielded a range of rates between 2.3 and $16 \mathrm{~mm} /$ year along various reaches of the fault (Burchfiel et al., 1991; Gaudemer et al., 1995; He et al., 1994; Lasserre et al., 1999; Li et al., 2009; Liu et al., 1992, 2018; Yuan et al., 1998; Zhang et al., 1988; Figure 1a). In the Laohu Shan section of the Haiyuan fault alone, He et al. (1994) and Yuan et al. (1998) suggested a slip rate of 3.4-5.6 mm/year. Both studies, however, lack precise offset and geochronological constraints. Subsequently, Lasserre et al. (1999) reported an average rate of $12 \pm 4 \mathrm{~mm}$ /year along the same section, 3 times faster than previous studies. Recently, Liu et al. (2018) reported an average slip rate of $\sim 4 \mathrm{~mm} /$ year over the past $45 \mathrm{ka}$ using optically stimulated luminescence (OSL) dating of the loess capping offset terraces. Geodetic studies based on interferometric synthetic aperture radar and GPS data suggest strain accumulation rate of 4-7 mm/year (Figure 1b), closer to the slower rates from geology (Cavalié et al., 2008; Daout et al., 2016; Gan et al., 2007; Jolivet et al., 2013; Wang et al., 2017).

To help to understand disparate late Quaternary fault slip rates arising from different studies, we reevaluate the displacement of terraces at the sites of Lasserre et al. (1999), by taking full advantage of new highresolution bare-earth digital elevation models (DEMs). We date these terraces as well using a combination of exposure-age dating, OSL, and ${ }^{14} \mathrm{C}$. Our study provides better constrained bracketing measurements of the slip rate at this site, and it suggests that the geological slip rate is the same as the geodetic loading rate here. Published higher slip rates here can be attributed to a bias toward the systematic use of lower-terrace reconstructions in interpreting the age of offset, similar to the argument on the geologic slip rate on the Altyn Tagh fault (e.g., Cowgill, 2007; Cowgill et al., 2009; Gold et al., 2009, 2011; Mériaux et al., 2004, 2005, 2012; $\mathrm{Xu}$ et al., 2005; Zhang et al., 2007).

\section{Geologic Setting}

The importance of localized deformation in accommodating Indo-Asian convergence is best illustrated by the fault system of the northeast Tibet plateau, which includes the Haiyuan, Altyn Tagh, Kunlun, and Xianshuihe strike-slip faults (Tapponnier \& Molnar, 1977). The $1,000-\mathrm{km}$-long Haiyuan fault follows the northern rim of the Tibet plateau from Hala Lake $\left(\sim 97^{\circ} \mathrm{E}\right)$ to Liupan Mountain (east of $\left.106^{\circ} \mathrm{E}\right)$. Along most of its length, the Haiyuan fault is characterized primarily by sinistral strike-slip, while to the east at Liupan Mountain, it transforms into thrusting with a slight left-lateral slip component.

The Laohu Shan section is located along the central portion of the Haiyuan fault and exhibits a strike of $100^{\circ}$ to $105^{\circ}$, which has a well-expressed rectilinear fault trace in geomorphology. This section is at the eastern end of the 260-km-long proposed "Tianzhu seismic gap" along the Haiyuan fault (Gaudemer et al., 1995). Paleoseismic investigation roughly corroborated this inference and found that the last major event occurred 1,000 years ago, probably associated with a historical earthquake in Common Era, 1092 (Liu-Zeng et al., 2007). Between major events occurring every 800-1,000 years, moderate magnitude earthquakes also occurred in this section, the recent ones being 20 October $1990 \mathrm{Mw} 5.8$ Tianzhu earthquake and $2000 \mathrm{Mw}$ 5.6 Jingtai earthquake (Committee for Chinese Earthquake Bulletin, 1990; Cai et al., 1992; US Geological Survey National Earthquake Information Center, 2000). The 35-km-long very eastern end of the Laohu Shan section is likely creeping at a rate of $\sim 5 \mathrm{~mm}$ /year indicated by the analysis of interferometric synthetic aperture radar data (Cavalié et al., 2008; Jolivet et al., 2013), despite that numerous geomorphic offsets of gullies were found to cluster at amounts of sell-separated increments, similar to the geomorphic offset pattern on noncreeping faults (Chen et al., 2018).

Our two study sites, which were first investigated by Lasserre et al. (1999), are $\sim 2 \mathrm{~km}$ apart and located near the western end of the Laohu Shan section, north of the Neogene Songshan basin (Figure 2). To the north of 

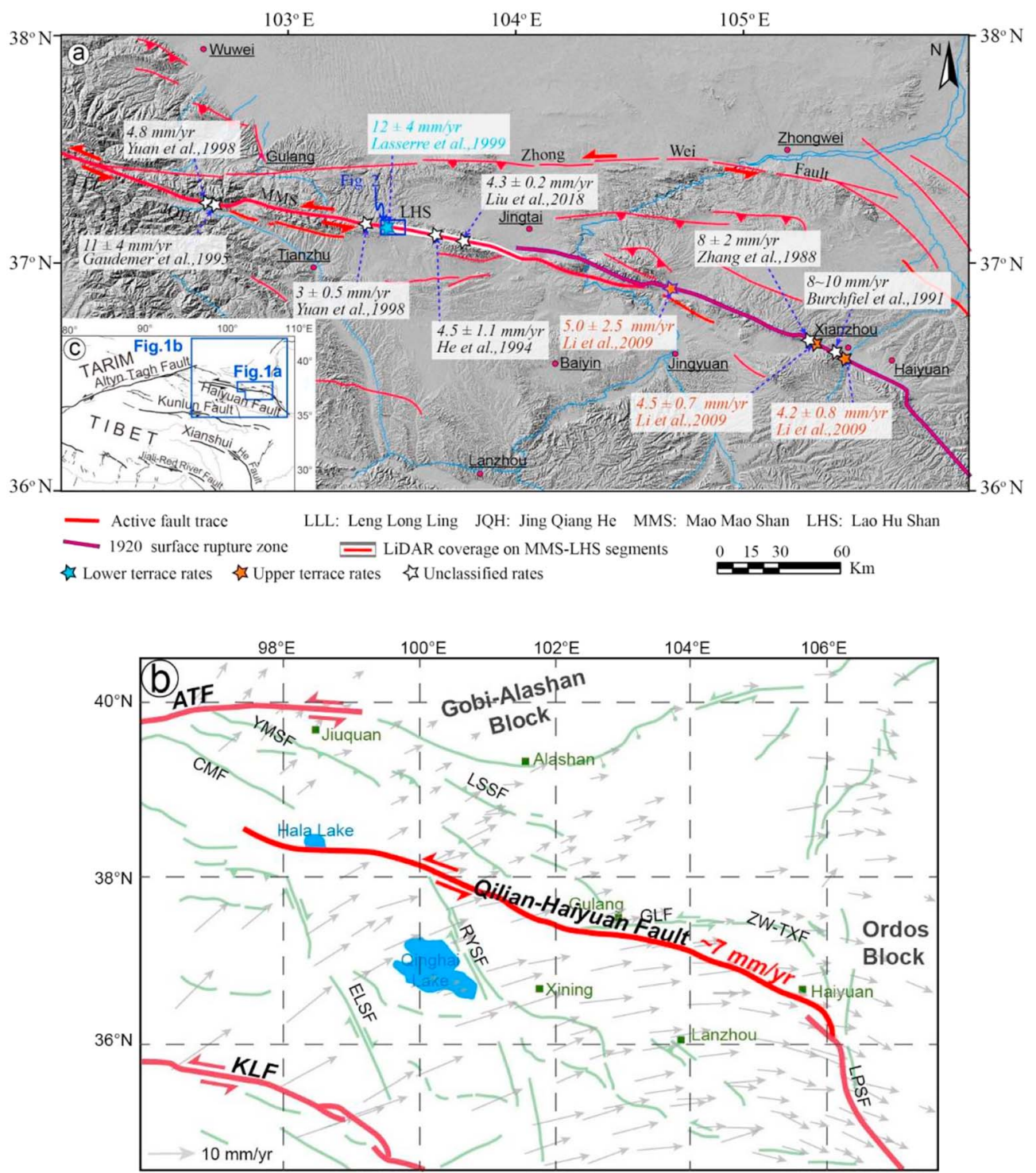

Figure 1. Tectonic setting of the study area. (a) Map showing fault geometry and locations of slip rates from previous studies along the Haiyuan fault, based on the Shuttle Radar Topography Mission data with 30-m resolution. Blue rectangle outlines Figure 2. (b) Regional GPS velocity field with respect to the stable Eurasian plate (Wang et al., 2017) and active faults in northern Tibetan Plateau. ATF = Altyn Tagh fault; KLF = Kunlun fault; YMSF = Yumu Shan fault; $\mathrm{CMF}=$ Changma fault; $\mathrm{LSSF}=$ Longshou Shan fault; GLF = Gulang fault; ZW-TXF = Zhongwei-Tongxin fault; LPSF = Liupan Shan fault; RYSF = Riyue Shan fault; ELSF = Ela Shan fault. (c) Map of major active faults and location of the Haiyuan fault in the Tibetan Plateau. LiDAR = Light Detection and Ranging.

the Haiyuan fault, the core of the Songshan exposes a basement composed of Silurian green schist with a culminating elevation above 4,000 $\mathrm{m}$, while Triassic sandstone is exposed south of the main fault.

A perennial channel, Majia Wan stream, originates from the range $\sim 1.5 \mathrm{~km}$ north of the fault. This stream crosses the Haiyuan fault and then joins with two other south-flowing streams with similar-size catchments. Sinistral displacements of streams, fluvial terraces, and risers are clearly evident along with the primary fault trace (Figure 3). A speculative, conjectural secondary fault branches northeast from the main trace at the intersection with the Majia Wan stream. The pair of faults bound a north-tilted push-up ridge that transitions into a $\sim 70-\mathrm{m}$-wide, $\sim 600-\mathrm{m}$-long depression to the east. Only the principal fault trace (the Haiyuan fault) shows distinct evidence of apparent horizontal slip and vertical throw. 


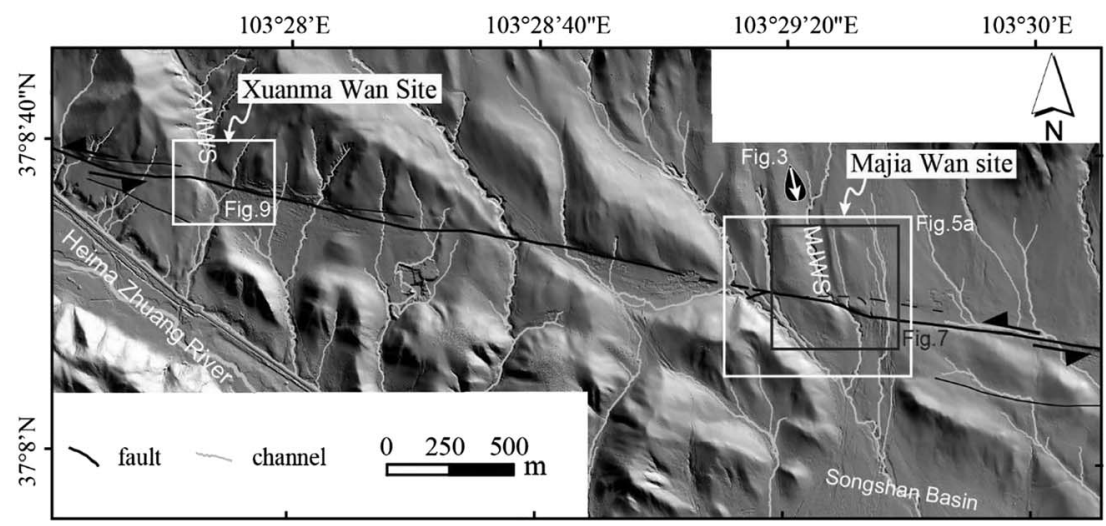

Figure 2. Light Detection and Ranging-derived 1-m high-resolution digital elevation model showing the locations of two study sites, the Majia Wan site and the Xuanma Wan site, which were previously studied by Lasserre et al. (1999).

In addition to the Majia Wan site, we also re-examined the Xuanma Wan site of Lasserre et al. (1999), located $\sim 2.2 \mathrm{~km}$ to the west of Majia Wan and to the north of the Heima Zhuang He ("He" as River in Chinese; Figure 2). Between the faceted spurs to the north and a string of hills to the south, there exist flat and distinct terraces cut by the Haiyuan fault. Several small rills flow down these facets and into Heima Zhuang He. The
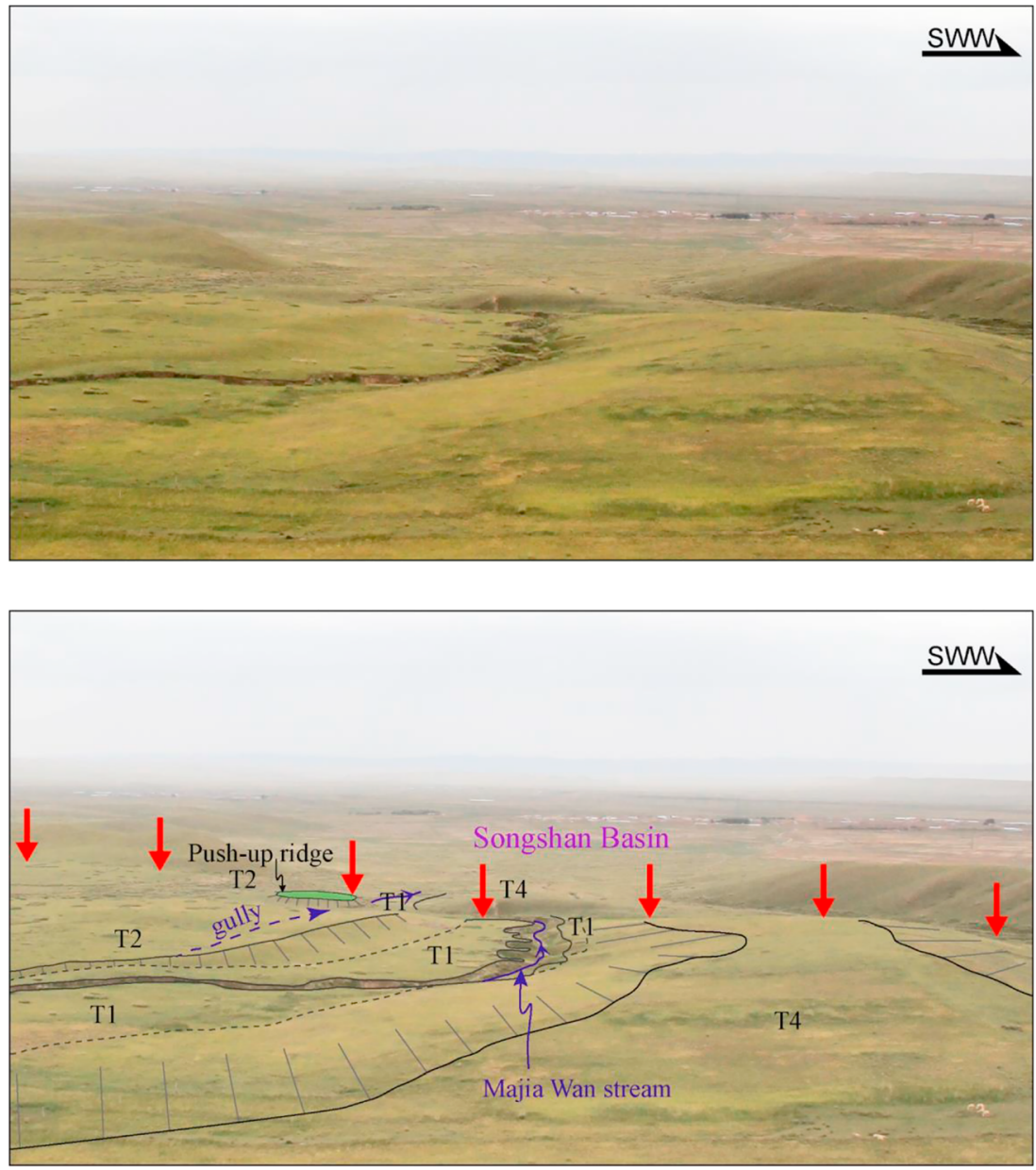

Figure 3. Field photo and sketch of the Majia Wan stream terraces. View toward the ESE, showing distinct terraces and fault. 
Xuanma Wan stream is also displaced by the Haiyuan fault. A detailed description of the geologic and geomorphic setting of this site is given in Lasserre et al. (1999).

\section{Methods}

\subsection{LiDAR DEM Analysis}

An airborne Light Detection and Ranging (LiDAR) scan of the Haiyuan fault was acquired in 2011 for studying the activity of the Haiyuan fault and assessing its related seismic hazard (Chen et al., 2014). The LiDAR data were processed to generate a 1-m resolution bare-earth DEM with vertical mean square errors less than $10 \mathrm{~cm}$ and the horizontal mean square errors less than $20 \mathrm{~cm}$ (Chen et al., 2014). In this paper, we extract a $\sim 8-\mathrm{km}^{2}$ region from this data set to reevaluate the offset geomorphic features and slip rate determination at the Majia Wan and Xuanma Wan sites (Figure 2).

The resolution of the LiDAR-derived DEM is high enough for meaningful calculation of various topographic indexes, such as hillshade, contour lines, slope, curvature, contributing area, and openness. Yokoyama et al. (2002) initially defined the openness to describe the degree of dominance or enclosure of a location on an irregular surface. The openness value is an angular measurement of the largest possible zenith (positive slope angle) and nadir (negative slope angle) averaged over eight azimuth directions $\left(0^{\circ}, 45^{\circ}, 90^{\circ}, 135^{\circ}\right.$, $180^{\circ}, 225^{\circ}, 270^{\circ}$, and $315^{\circ}$ ) within a special window size. That is the openness has two perspectives, including negative values and positive values, which represents concavity and convexity of the surface, respectively. The openness measure is calculated within a moving window. In general, a large window size (a few hundred meters) will emphasize the macrolandscape, while a small window size (a few meters) will enhance local microtopography. We apply a 10-m window to emphasize local landforms in this research. To better express the detailed topographic features, Chiba et al. (2008) proposed Red Relief Image Map to extend the openness parameter by using topographic slope gradient information overlain by the difference, I, of positive openness and negative openness:

$$
I=\left(O_{p}-O_{n}\right) / 2
$$

where $O_{p}$ is positive openness and $O_{n}$ is negative openness. We calculated the negative openness, positive openness, and I with our high-resolution DEM in Landserf 2.3 software (http://www.landserf.org/) and then merge this value with a topographic slope map generated in ArcGIS 10.2 (https://www.esri.com). Since it has been proved that people's eyes are more sensitive to red color (Chiba et al., 2008), the RRIM map is always expressed by gray-scale image layer of openness difference $(I)$ overlapped by red color topographic slope layer. Besides this, we extracted D-infinity contributing area parameter with TauDEM toolbox, which is the contribution area per unit contour length using the multiple flow direction D-Infinity approach. Superposition of D-infinity contributing area and RRIM provides a better image of the microtopography. We also used multiple topographic profiles spaced 8 to $20 \mathrm{~m}$ apart to depict the abrupt changes in the slope of the terrain. These changes provide added clues for tracing the crest and base of a terrace riser.

\subsection{Terraces Dating}

Geochronological techniques applied include ${ }^{14} \mathrm{C}$, optically stimulated luminescence, and in situ cosmogenic ${ }^{10} \mathrm{Be}$. Material for ${ }^{14} \mathrm{C}$ dating was collected at a depth of $\sim 120 \mathrm{~cm}$ in a stream-cut face of the east bank of Majia Wan stream and analyzed by accelerator mass spectrometer at Beta Analytic Inc., in Miami. Ages from this study and from Lasserre et al. (1999) were calibrated using the Libby half-life (5,568 years; Table 1). Prior studies have documented the ubiquity of loess deposits in the western China (Hetzel et al., 2004, 2006; Zhang et al., 2015), including our study area. All of our OSL samples were collected in stainless steel tubes $5 \mathrm{~cm}$ in diameter and $30 \mathrm{~cm}$ in length. The sample preparation and measurement of these samples were conducted under subdued red laboratory light at the State Key Laboratory of Earthquake Dynamics in the China Earthquake Administration following the sample treatment methods described in the supporting information of Yang et al. (2018). The pertinent sample details and ages obtained are presented in Table 2.

We applied a depth profile approach for cosmogenic ${ }^{10} \mathrm{Be}$ dating with amalgamated samples of small pebbles (Anderson et al., 1996). Samples were processed following the revised method of von Blanckenburg et al. 
Table 1

Radiocarbon Results From the Majia Wan Site, Haiyuan Fault

\begin{tabular}{|c|c|c|c|c|c|c|c|c|c|}
\hline Sample name & $\begin{array}{l}\text { Laboratory } \\
\text { number }^{\mathrm{a}}\end{array}$ & ${ }^{\delta 13} \mathrm{C}(\% \circ)$ & $\begin{array}{l}{ }^{14} \mathrm{C} \text { age }{ }^{\mathrm{b}} \\
\text { (years B.P.) }\end{array}$ & $\begin{array}{l}\text { Calibrat } \\
\text { (years B }\end{array}$ & $\begin{array}{l}\text { ed age } \\
P . \pm 2 \sigma)\end{array}$ & Material & $\begin{array}{c}\text { Sample } \\
\text { depth }(\mathrm{cm})\end{array}$ & $\begin{array}{l}\text { Stratigraphy on } \\
\text { sample location }\end{array}$ & Description \\
\hline T1C-6 & Beta-454398 & -22.9 & $8,500 \pm 30$ & $9,445 \pm 30$ & \multirow{4}{*}{$9,867 \pm 164$} & Charcoal & 150 & Sand layer & This study \\
\hline SSC1.1 & SSC1.1 & -25 & $9,060 \pm 160$ & $10,094 \pm 184$ & & \multirow{3}{*}{ Charcoal } & \multirow[t]{3}{*}{120} & \multirow{3}{*}{$\begin{array}{l}\text { Beige colored reworked } \\
\text { loess under small angular } \\
\text { pebble beds }\end{array}$} & \multirow{3}{*}{$\begin{array}{l}\text { Lasserre et al. } \\
\text { (1999) }\end{array}$} \\
\hline SSC1.2 & SSC1.2 & -25 & $8,750 \pm 100$ & $9,711 \pm 177$ & & & & & \\
\hline SSC1.3 & SSC1.3 & -25 & $8,830 \pm 50$ & $9,795 \pm 112$ & & & & & \\
\hline
\end{tabular}

${ }^{\mathrm{a}}$ Sample of this study processed at Beta Analytic Inc., Florida (Beta). Sample of Lasserre et al. (1999) processed at Lawrence Livermore National Laboratory.

${ }^{\mathrm{b}}$ The ${ }^{14} \mathrm{C}$ age was calculated using the Libby half-life of 5,568 years and following the conventions of Stuiver and Polach (1977). ${ }^{\mathrm{c}} \mathrm{Calibration}$ of this study calculated using the databases associated with the 2013 INTCAL program. Calibration of Lasserre et al. (1999) according to Stuiver and Reimer (1993).

(2004) at the Helmholtz Laboratory for the Geochemistry of the Earth Surface at the GFZ German Research Center for Geosciences. Accelerator mass spectrometry measurements were conducted at Cologne University in Germany (Dewald et al., 2013; Table 3).

We extended the method proposed by Hetzel et al. (2004) to infer terrace ages from depth profile samples buried by loess accumulated over only the latter part of the terrace history. For clarity, we ignore the effect of radioactive decay of ${ }^{10} \mathrm{Be}$ because target landform ages are much shorter in its half-life. As the schematic drawing of Figure 4 illustrates, this approach divides the duration, $t$, since the terrace was abandoned, into $t_{1}$, which is the time elapsed between the abandonment of the terrace and beginning of loess deposition, and $t_{2}$, which denotes the time since the onset of loess accumulation, that is given by the contact age of loess immediately above fluvial deposits. The concentration, $C_{\text {tot }}$, of ${ }^{10} \mathrm{Be}$ in sediments at the contact with loess is the sum of three terms:

$$
C_{\mathrm{tot}}=C_{1}+C_{2}+C_{\mathrm{inh}}
$$

$C_{1}$ and $C_{2}$ accumulate over $t_{1}$ and $t_{2}$, respectively, and $\mathrm{C}_{\mathrm{inh}}$ is the inherited ${ }^{10} \mathrm{Be}$ acquired in the sediment prior to terrace deposition. Loess accumulates on the stable terrace surface at an assumed constant rate $\alpha$ over $t_{2}$, and the concentration $C_{2}$ increases until the time we collect the samples. This concentration is given by

$$
C_{2}=\int_{0}^{\mathrm{t}_{2}} P_{0} e^{-\left(\frac{\rho_{g} d}{\Lambda}+\frac{\rho_{1} \alpha t_{2}}{\Lambda}\right)} \mathrm{d} t
$$

where $d$ denotes the depth of a ${ }^{10} \mathrm{Be}$ sample below the base of the loess, $\rho_{1}$ is the density of loess $\left(1.4 \mathrm{~g} / \mathrm{cm}^{3}\right)$, $\rho_{\mathrm{g}}$ is the density of sediment $\left(2 \mathrm{~g} / \mathrm{cm}^{3}\right.$ at our study site $), \Lambda$ is the attenuation length of terrestrial in situ cosmogenic nuclides (TCNs) production ( $160 \mathrm{~g} / \mathrm{cm}^{2}$; Braucher et al., 2011), $P_{0}$ is the surface production of ${ }^{10} \mathrm{Be}$ based on the scaling scheme (Stone, 2000), $\alpha$ is the temporally steady accumulation rate of loess, and $t_{2}$ is the contact age. This equation is solved for the boundary conditions to yield

$$
C_{2}=\frac{P_{0} \Lambda}{\rho_{l} \alpha} e^{-\frac{\rho_{g} d}{\Lambda}}\left(1-e^{-\frac{\alpha t_{2} \rho_{l}}{\Lambda}}\right)
$$

For the surface ${ }^{10} \mathrm{Be}$ production rate, $P_{0}$, we use a value of 4.5 atoms/g/a as the ${ }^{10} \mathrm{Be}$ reference sea level-high latitude production rate recalibrated according to (Siame et al., 2012). Subtracting $C_{2}$ from the total concentration, we solve for $t_{1}$ and $C_{\text {inh }}$ from the age-depth relationship:

$$
C_{\text {tot }}-C_{2}=P_{0} t_{1} e^{-\frac{d \rho g}{\Lambda}}+C_{\text {inh }}
$$

We simplify equation (5) to a linear relationship:

$$
C_{\text {tot }}-C_{2}=M x+C_{\text {inh }}
$$




\begin{tabular}{|c|c|c|c|c|}
\hline 焉 & 1 1 & $\begin{array}{l}\stackrel{0}{i} \\
+1 \\
\infty \\
\stackrel{\sim}{\sim}\end{array}$ & I & $\begin{array}{l}\underset{+}{+} \\
+1 \\
\dot{+} \\
\stackrel{n}{+}\end{array}$ \\
\hline 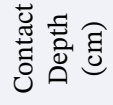 & I I & ฉ & I & తి \\
\hline 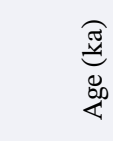 & $\begin{array}{ll}\hat{i} & n \\
0 \\
+1 & +1 \\
0 & 0 \\
0 & 0 \\
i & \ddots\end{array}$ & 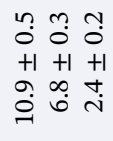 & $\begin{array}{l}\hat{i} \\
+1 \\
a \\
\infty\end{array}$ & 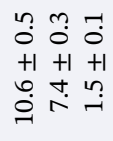 \\
\hline 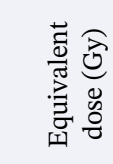 & $\begin{array}{ll}\infty & 0 \\
\infty & \dot{r} \\
+1 & +1 \\
a & 0 \\
& 0 \\
a & \dot{m}\end{array}$ & 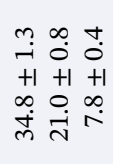 & $\begin{array}{l}\stackrel{\circ}{+} \\
\text { + } \\
+1 \\
\hat{i} \\
\text { i }\end{array}$ & 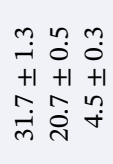 \\
\hline 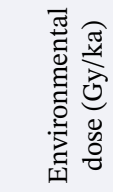 & $\begin{array}{ll}m & m \\
0 & 0 \\
+1 & +1 \\
+ & 0 \\
\dot{m} & \dot{m}\end{array}$ & 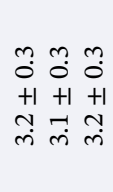 & $\begin{array}{l}m \\
0 \\
+1 \\
m \\
m\end{array}$ & 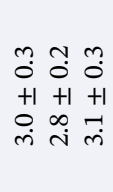 \\
\hline 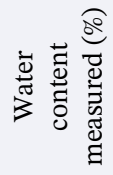 & 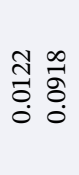 & 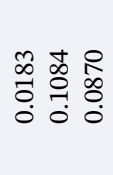 & 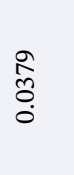 & 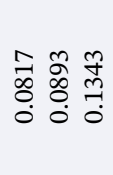 \\
\hline 党 & 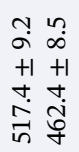 & 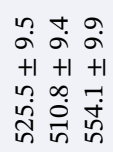 & $\begin{array}{l}\hat{a} \\
+1 \\
\infty \\
\dot{j}\end{array}$ & 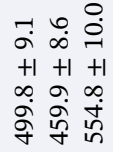 \\
\hline 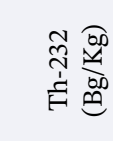 & 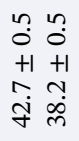 & $\begin{array}{lll}n & n & 0 \\
0 & 0 & 0 \\
+1 & +1 & +1 \\
0 & \infty & 0 \\
\dot{y} & \dot{y} & \dot{y}\end{array}$ & $\begin{array}{l}n \\
0 \\
+1 \\
n \\
\tilde{y}\end{array}$ & 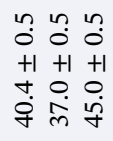 \\
\hline 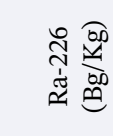 & $\begin{array}{ll}n & n \\
0 & 0 \\
+1 & +1 \\
r & r \\
\infty & \stackrel{0}{i}\end{array}$ & $\begin{array}{ccc}n & 0 & n \\
0 & 0 & 0 \\
+1 & +1 & +1 \\
\sim & + & - \\
-1 & \infty & 0 \\
m & m & 0\end{array}$ & $\begin{array}{l}n \\
0 \\
+1 \\
0 \\
0 \\
i\end{array}$ & 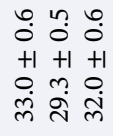 \\
\hline 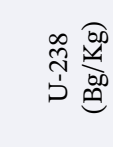 & $\begin{array}{ll}m & n \\
0 & 0 \\
+1 & +1 \\
+1 & \infty \\
\Rightarrow & 0 \\
\Rightarrow & 0\end{array}$ & 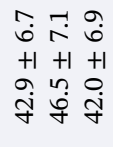 & $\begin{array}{l}\dot{+} \\
\dot{b} \\
+1 \\
\dot{\sigma} \\
\dot{q}\end{array}$ & 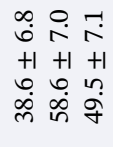 \\
\hline 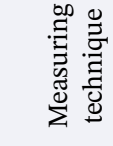 & $\sum_{n}$ & $\sum_{i}^{\infty} \sum_{i=s}^{\infty}$ & $\sum_{n}^{\infty}$ & $\sum_{i}^{\infty} \sum_{i=s}^{\infty}$ \\
\hline 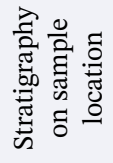 & 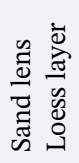 & 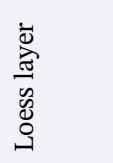 & 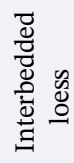 & 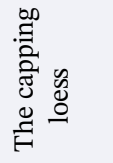 \\
\hline 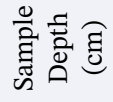 & in & ஓ テี & $\stackrel{一}{=}$ & 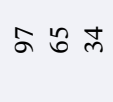 \\
\hline 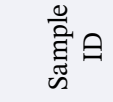 & 공 & $\stackrel{\sim}{m} \stackrel{\vec{m}}{\dot{m}}$ & $\stackrel{\check{x}}{\check{\gamma}}$ & 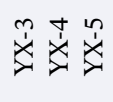 \\
\hline & 实 & 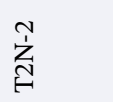 & $\tilde{E}$ & \\
\hline
\end{tabular}

where the slope, $M=P_{0} t_{1}$, and the dependent variable $x=e^{-\frac{d \rho_{g}}{\Lambda}}$. Through linear regression, we determine the best fit and error for $C_{\mathrm{inh}}$ and $M$ from our four TCN samples. With this estimate for $t_{1}$, we calculate the whole time since the abandonment of terrace by

$$
t=t_{1}+t_{2}
$$

\section{Geomorphic Mapping}

At the Majia Wan site, three groups of terraces can be distinguished. From low to high relative elevation, and thus from youngest to oldest, these terraces are designated T1, T2, and T4. From the extracted topographic profiles along both sides of fault zone, these terraces show increasing elevation above the modern riverbed with overall tilting toward the SSE (Figures 5 and 6). The youngest and lowest set of terraces (T1) is mainly preserved along the east side of Majia Wan stream, accompanied by several extremely narrow patches at the west side of the stream north of the fault. To the south of the fault, T1 spreads in a fan-shaped manner along both sides of Majia Wan stream, which is presently incised $\sim 3.2 \mathrm{~m}$ below the T1 surface (Figures $5 \mathrm{~b}$ and $5 \mathrm{c}$ ). The main tread of T2 forms a broad, smooth surface east side of Majia Wan stream to the north of the Haiyuan fault, narrowing to a bench south of the fault and ending in an indistinguishable boundary with $\mathrm{T} 1$ to the south. Adjacent to the fault, animal and/or manmade rills obscured the riser between $\mathrm{T} 2$ and $\mathrm{T} 1$, making it difficult to recognize the west edge of $\mathrm{T} 2 \mathrm{immediately}$ south of the fault. To the north of the fault, within $\mathrm{T} 2$, an isolated remnant topographic high stands $\sim 8.0 \mathrm{~m}$ above the streambed. A smooth and shallow gully is inset into T2 immediately to the west of this high remnant (Figures 6 and 7). The oldest terrace surface (T4) is preserved west of Majia Wan stream, where it stands as much as $\sim 13 \mathrm{~m}$ above the nearby riverbed (Figure 5). The terrace crest of $\mathrm{T} 4$ exhibits a convex shape with a narrow flat tread. In the vicinity of the fault zone, the $\mathrm{T} 4$ terrace tread deviates from its north-south orientation, likely due to deformation by faulting (Figure 6).

With exception of immediately south of the Haiyuan fault where obscured by rilling, the intervening riser between $\mathrm{T} 2$ and $\mathrm{T} 1$ (the T2/T1 riser) is well defined along the east bank of Majia Wan stream. North of the fault, the T2/T1 riser trends straight and at an angle to the fault trace to within a few meters of the fault. South of the fault, the T1/T2 riser is obscured by closely spaced north-south trending rills formed by animal and/or manmade trails. The underlying topography suggests that the riser is unusually wide in this area and narrows to the south away from the fault (Figure 6). Possible origins for this wide riser include collapse of the free face of the adjacent fault scarp, gradual offlap of Majia Wan stream as slip accrued on the fault, or deposition of materials eroded from $\mathrm{T} 2$ further north of the Haiyuan fault. To better depict the distinct crest and base of the T2/T1 riser to the south of the fault, we combined multiple topographic profiles and Red Relief Image Map covered by the contributed area map as an assistant (Figures 6 and 7). We thus made both the crest and base of the T2/T1 riser as the offset geomorphic markers (Figure 8).

Likewise, we also remapped the Xuanma Wan site using the high-resolution DEM combining the contour lines and derived DEM products (Figures 9a and 9b). This mapping shows distinct terraces with clearly distinguishable risers. Our mapping confirms the overall mapping by Lasserre et al. (1999), except that the lowest terrace level T0 is now distinguished (Figures $8 \mathrm{~b}, 8 \mathrm{~d}$, and $8 \mathrm{e}$ ).

\section{Geochronology}

We augmented the original ${ }^{14} \mathrm{C}$ dating of $\mathrm{T} 1$ from Lasserre et al. (1999) with one additional sample N-T1 and applied optically stimulated luminescence and in situ terrestrial cosmogenic ${ }^{10} \mathrm{Be}$ to date $\mathrm{T} 2$. We excavated two pits (T2N-1 and T2N-2) on the T2 north of the fault to expose the stratigraphy of $\mathrm{T} 2$ terrace, one pit (T2S) in triangular zone of sloping $\mathrm{T} 2 / \mathrm{T} 1$ riser to the south of the Haiyuan fault to constrain the west edge of T2. We took high-resolution 
Table 3

Measured ${ }^{10}$ Be Concentrations at the Majia Wan Site, Haiyuan Fault

\begin{tabular}{|c|c|c|c|c|c|c|c|c|c|c|}
\hline \multirow[b]{2}{*}{ Trench } & \multirow{2}{*}{$\begin{array}{l}\text { Sample } \\
\text { ID }\end{array}$} & \multirow{2}{*}{$\begin{array}{l}\text { Latitude } \\
\left({ }^{\circ} \mathrm{N}\right)\end{array}$} & \multirow{2}{*}{$\begin{array}{c}\text { Longitude } \\
\left({ }^{\circ} \mathrm{E}\right)\end{array}$} & \multirow{2}{*}{$\begin{array}{c}\text { Elevation } \\
\text { (m) }\end{array}$} & \multirow{2}{*}{$\begin{array}{c}\text { Depth }^{\mathrm{a}} \\
(\mathrm{cm})\end{array}$} & \multirow{2}{*}{$\begin{array}{l}\text { Thickness } \\
(\mathrm{cm})\end{array}$} & \multirow[b]{2}{*}{ Shielding } & \multirow{2}{*}{$\begin{array}{c}{ }^{10} \mathrm{Be} /{ }^{9} \mathrm{Be}^{\mathrm{b}} \\
\left(10^{-12}\right)\end{array}$} & \multicolumn{2}{|c|}{${ }^{10} \mathrm{Be}$ concentration $\left(10^{5}\right.$ atoms $\left./ \mathrm{g}\right)$} \\
\hline & & & & & & & & & Value & Error $^{\mathrm{c}}$ \\
\hline \multirow[t]{4}{*}{$\mathrm{T} 2 \mathrm{~N}-2$} & T3-95 & 37.14046 & 103.49173 & 2,799 & 95 & 5 & 1 & 2.101 & 9.43 & 0.311 \\
\hline & T3-125 & & & & 125 & & & 1.809 & 7.66 & 0.255 \\
\hline & T3-215 & & & & 215 & & & 1.821 & 6.70 & 0.224 \\
\hline & T3-295 & & & & 295 & & & 1.294 & 5.06 & 0.167 \\
\hline \multirow[t]{4}{*}{$\mathrm{T} 2 \mathrm{~S}$} & YX-150 & 37.1385 & 103.49257 & 2,804 & 150 & 5 & 1 & 2.899 & 10.01 & 0.326 \\
\hline & YX-180 & & & & 180 & & & 1.111 & 4.52 & 0.153 \\
\hline & $Y X-260^{\S}$ & & & & 260 & & & 1.303 & 4.70 & 0.157 \\
\hline & YX-320 & & & & 320 & & & 0.579 & 2.16 & 0.075 \\
\hline
\end{tabular}

${ }^{\mathrm{a}}$ Depth beneath the surface. ${ }^{\mathrm{b}}$ Measured ${ }^{10} \mathrm{Be} /{ }^{9} \mathrm{Be}$ ratios were corrected for procedural blanks and calculated by using half-life for ${ }^{10} \mathrm{Be}$ of $1.36 \pm 0.07 \times 106$ year. This standardization is equivalent to 07KNSTD within rounding error. Absolute calibration of ${ }^{10} \mathrm{Be}$ accelerator mass spectrometry standards (2007) Nuclear Instruments and Methods in Physics Research. ${ }^{\mathrm{c}}$ Uncertainties on ${ }^{10} \mathrm{Be}$ concentrations are calculated using the error propagation method (Balco, 2006).

photographs and recorded detailed stratigraphic observations of each excavation (Figure 10). All of these pits reveal a different depth of loess, from 60 to $120 \mathrm{~cm}$, capping T2 terrace deposits.

\subsection{Radiocarbon Dating on $\mathrm{T} 1$}

Lasserre et al. (1999) reported three ${ }^{14} \mathrm{C}$ ages from $\mathrm{T} 1$, extracted at a depth of $\sim 120 \mathrm{~cm}$ in a stream-cut face of the west bank of Majia Wan stream. The average of three samples yields a date of 9,867 \pm 164 year B.P. Due to the existing age constraints already provided, we only added one charcoal sample to this data set. We extended an additional $50 \mathrm{~cm}$ into the stream-cut face on the eastern bank of T1, upstream of the fault, which is a different position to Lasserre et al. (1999), to more precisely describe its stratigraphy and obtain the

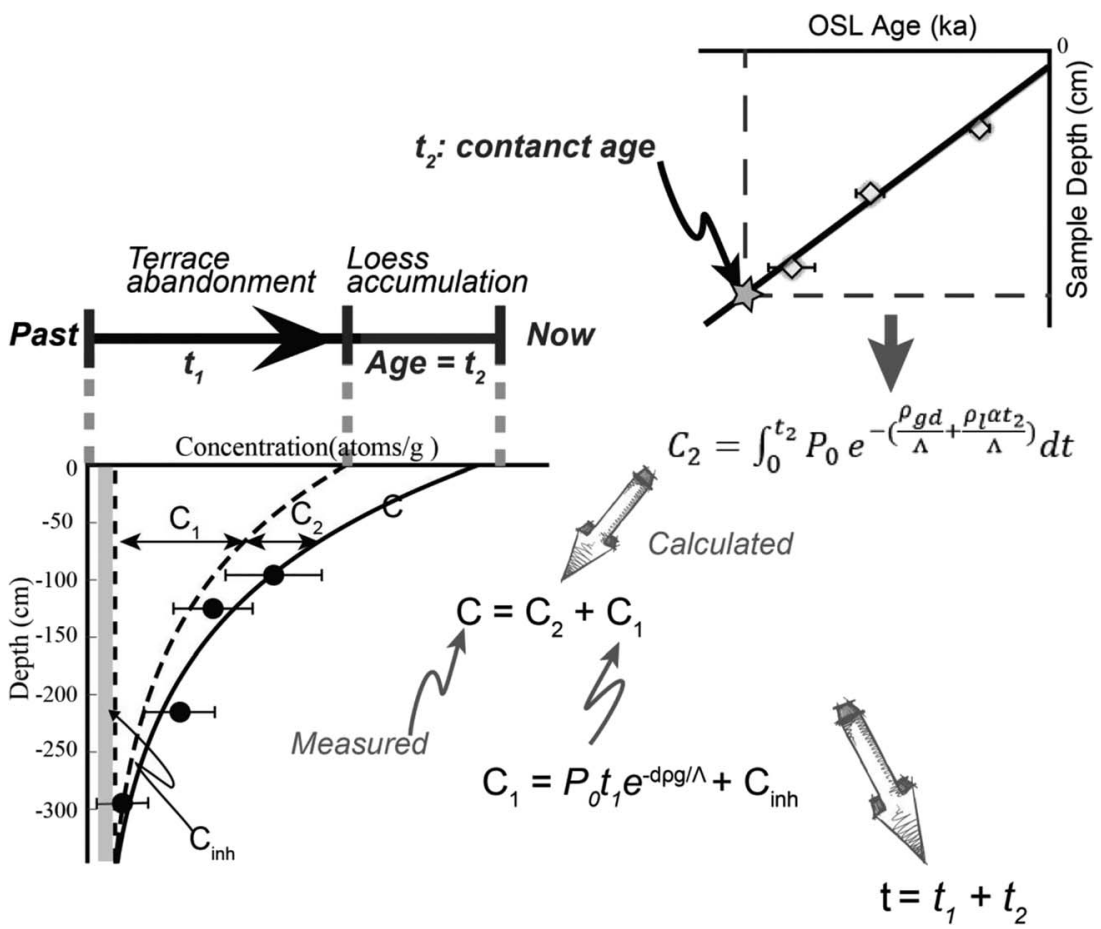

Figure 4. Carton showing the concept and various parameters used in terrace dating, using those ${ }^{10} \mathrm{Be}$ and optically stimulated luminescence (OSL) samples collected in the pit T2N-2. 


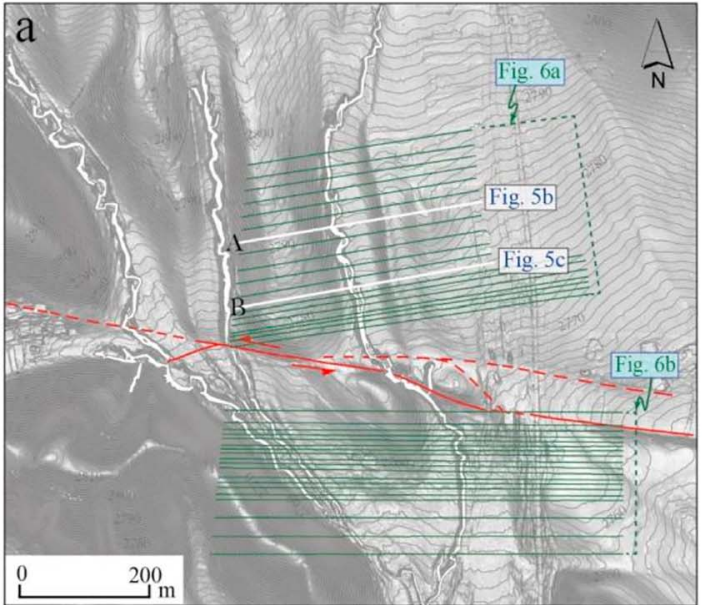

Profile A

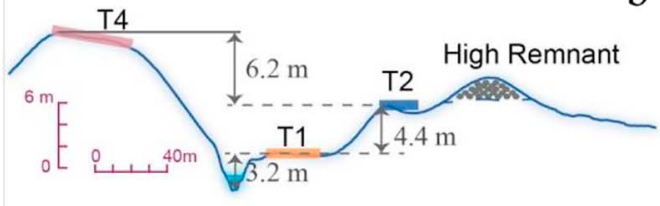

Profile B

C

Figure 5. Topographic profiles extracted from Light Detection and Ranging digital elevation model, showing distinctively different levels of terrace surfaces at the Majia Wan site. (a) Locations of topographic- and curvature profiles. (b and c) Profiles located on the north of the Laohu Shan fault. Also shown are two depth profiles at the position of profile B, indicating 2-m elevation difference between optically stimulated luminescence (OSL) sample in T2N-1 and TCN samples in $\mathrm{T} 2 \mathrm{~N}-2$.
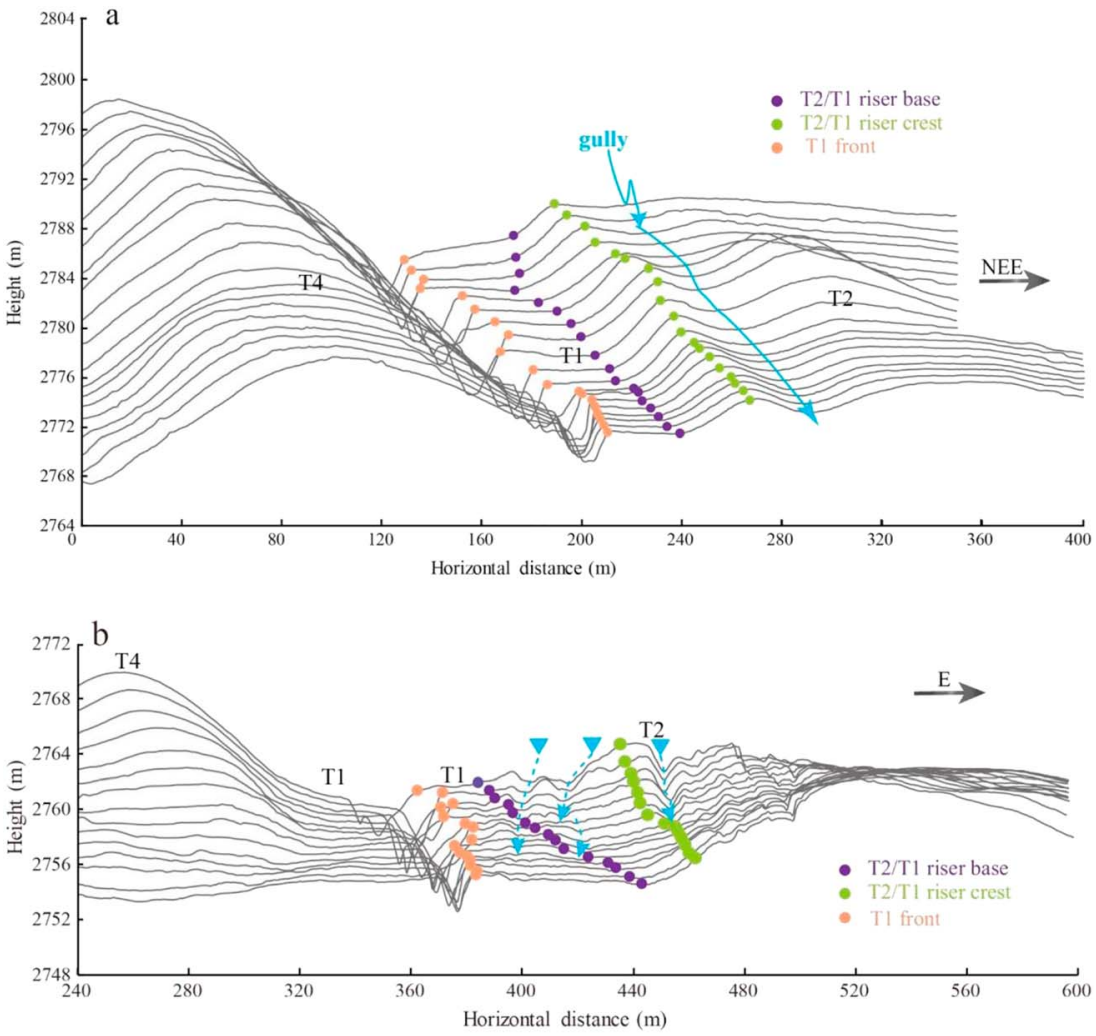

Figure 6. Multiple topographic profiles transect distinct terraces. (a) Successive northern profiles show the topography change as closing to the fault. Those profiles also indicate that the gully is located in the T2 tread. (b) Sequential topographic profiles located on the southern side of the Haiyuan fault. These profiles also show a more gradual T2/T1 riser than that on the northern and upstream side of the fault. 

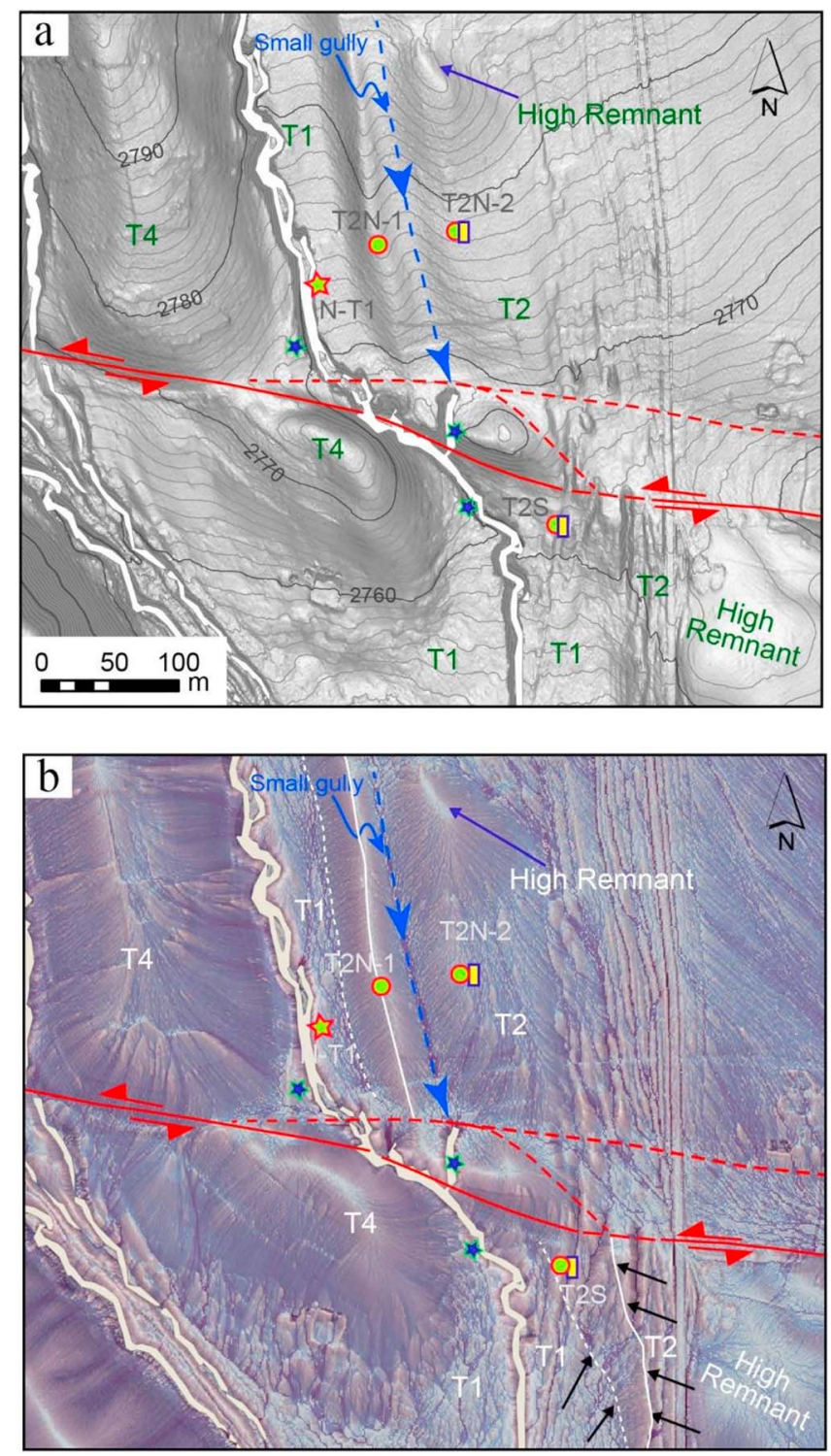

Figure 7. Characterization of the microtopography of the Majia Wan site by different morphologic enhancement methods. (a) Hillshade relief map overlain by 1-m contour lines. (b) RRIM overlain by contributing area map, based on Landserf software and TauDEM toolbox, respectively. Black arrows denote the crest and base of the T2/T1 riser, as well as the white and dashed lines indicate. Also shown are location of samples, whose symbols are the same as in Figure 8. additional carbon sample. This deposit exhibits well-defined stratification, with well-sorted, clast-supported angular granules interbedded with two different thicknesses of reworked sand and loess, and overlain by $\sim 60$ $\mathrm{cm}$ of loess. We collected an organic sample at a depth of $\sim 150 \mathrm{~cm}$ for radiocarbon $\left({ }^{14} \mathrm{C}\right)$ dating (T1C-6; Figure 10a). It yields a slightly younger age of $9,445 \pm 30$ year B.P., which basically confirms, yet with a reduced error, the age acquired by Lasserre et al. (1999; Table 1). We use our sample to constrain the maximum abandonment age of $\mathrm{T} 1$ as $9,445 \pm 30$ year B.P.

\subsection{Dating From T2N-1}

Both pits north of the fault (T2N-1 and T2N-2) exhibit similar deposits with poorly to well-sorted angular clasts including a sand lens and capped by 70 - tot $90-\mathrm{cm}$ depth of loess (Figures 10b and 10c). In T2N-1 we collected one OSL sample from a sand lens within the T2 deposit (J2-1) and one sample from the overlying loess (J2-2; Figure 10b and Table 2). The deeper sample has an age of $28.0 \pm 2.7 \mathrm{ka}$, which sets an upper limit for the age of $\mathrm{T} 2$.

\subsection{Dating From $\mathrm{T} 2 \mathrm{~N}-2$}

We collected four ${ }^{10} \mathrm{Be}$ samples $\mathrm{T} 2 \mathrm{~N}-2$ to assemble a depth profile, and three OSL samples to date accumulation of the overlying loess. The OSL ages are ordered in a correct stratigraphic sequence and indicate steady loess accumulation since the latest Pleistocene (Table 2). By plotting OSL age versus loess depth, we predict the onset of loess accumulation on T2 at $12.8 \pm 2.0 \mathrm{ka}$, at an accumulation rate of $6.8 \mathrm{~cm} / \mathrm{ka}$ (Figure 4). Using equations (2)-(7), we model our four ${ }^{10} \mathrm{Be}$ samples to estimate that the $\mathrm{T} 2$ terrace deposit was originally abandoned at $26.0^{+1.6} /-1.5 \mathrm{ka}$ (Figure 4). The $\mathrm{T} 2$ deposits carry an inherited ${ }^{10} \mathrm{Be}$ concentration of 5.14 $\pm 0.34 \times 10^{5}$ atoms $/ g$ (Table 4 and Figure 10c). In this calculation, we have not enough samples to well constrain the confidence interval, which tells us how confident we are in the results. Therefore, it is necessary to use the $t$ distribution, which is a statistical probability distribution to estimate the mean of a normally distributed population when the sample size is small and the standard deviation is unknown, to acquire a reasonable confidence interval (Kotz, 2004). First, we had a group of three different ages with a mean age of $26.0 \mathrm{ka}$, which is the degree of freedom (df) should be 2. Second, we set our confidence level to be $90 \%$, in terms of $\alpha=$ $(1 \%-90 \%) / 2=0.05$. Combining df and $\alpha$, we then determine $t=2.920$ by checking the $t$ value table. Finally, using the error corrected formula, which is $t \times \sigma$, where $\sigma$ denotes the standard deviation, we thus determined the exposure age of $26.0 \pm 4.5 \mathrm{ka}$ with $90 \%$ confidence level (Table 4).

\subsection{Dating From T2S}

From T2S, we collected three OSL samples from the capping loess, one OSL sample from interbedded loess within the $\mathrm{T} 2$ sediments and four ${ }^{10} \mathrm{Be}$ samples arranged as a depth profile (Figure 10d). The stratigraphy in this pit can be divided into the capping 120-cm loess layer and two gravel layers (upper and lower) separated by a $10-\mathrm{cm}$-thick reworked loess lens. The OSL samples from the capping loess yield the contact age, $t_{2}$, of $15.39 \pm 4.14 \mathrm{ka}$ and a loess accumulation rate of $6.7 \mathrm{~cm} / \mathrm{ka}$. The ${ }^{10} \mathrm{Be}$ concentrations of the four TCN samples do not decrease monotonically with depth, as would be expected from a simple sediment accumulation history. There is likely a gap in sedimentation between the gravel layers, explaining higher concentration of YX260 relative to YX-180. This is also supported by the OSL date of $80.9 \pm 7.7 \mathrm{ka}$ from the reworked loess between these layers. The high concentration of sample YX-150 is not easily explained but may reflect 

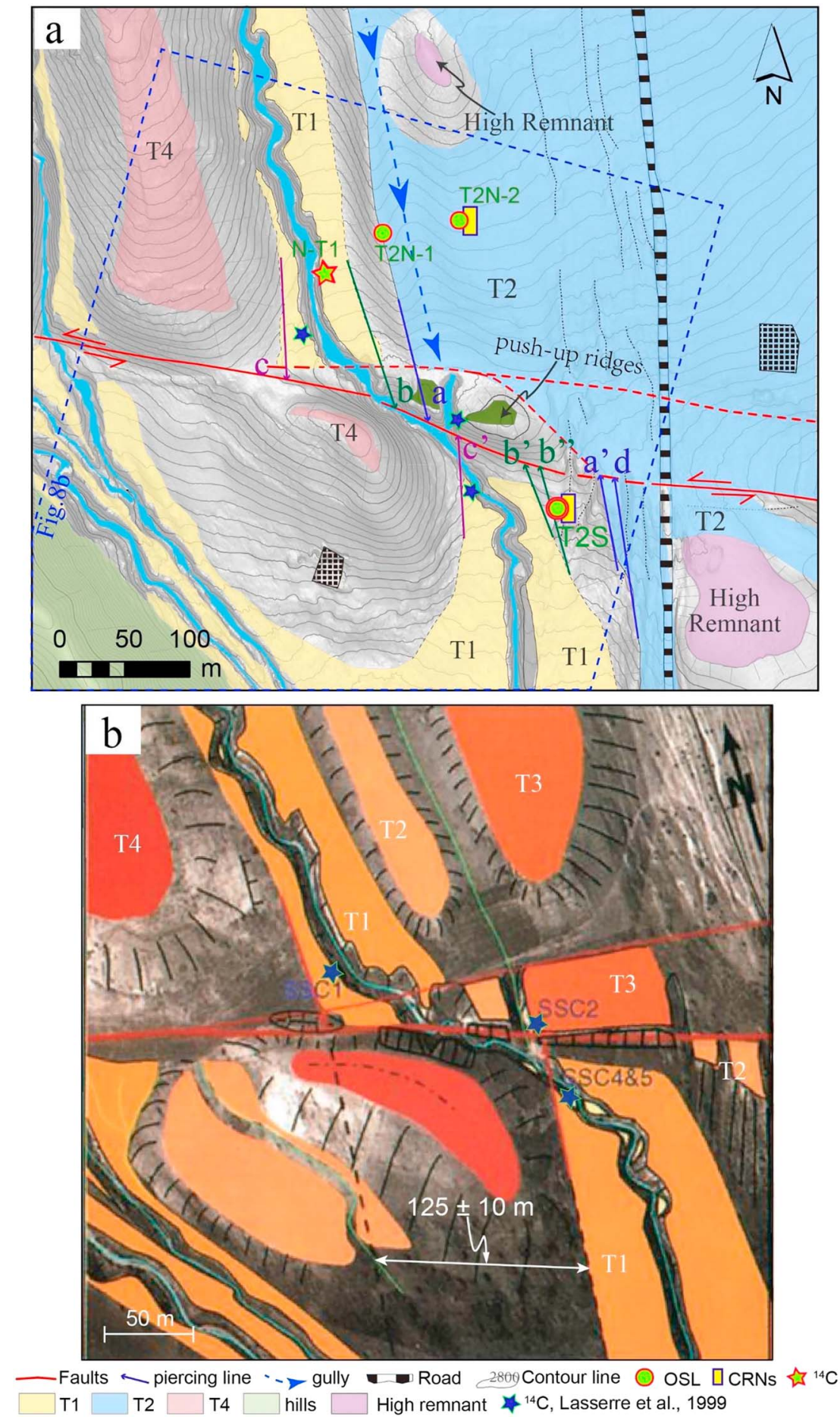

Figure 8. Geomorphic interpretation of the Majia Wan site. (a) Mapping from this study showing the piercing lines of different displacement. Also shown are locations of depth profiles for terrace surface dating. The rectangle with a dashed blue line marks the research area of Lasserre et al. (1999), showing as Figure 8b. (b) Geomorphic map covering on a highresolution photograph from Lasserre et al. (1999).

inadequate averaging of small pebbles. Collectively, these samples cannot be modeled as a depth profile, and thus, we correct individual concentrations for loess accumulation only and report maximum surface exposure ages, $t$, using equation (5) to calculate $t_{1}$ assuming that $C_{\text {inh }}=0$. We apply the same densities for loess and gravel as applied for T2N-2. We calculate maximum ages of $50.1 \pm 5.6 \mathrm{ka}$ and $32.2 \pm 4.9 \mathrm{ka}$ for 

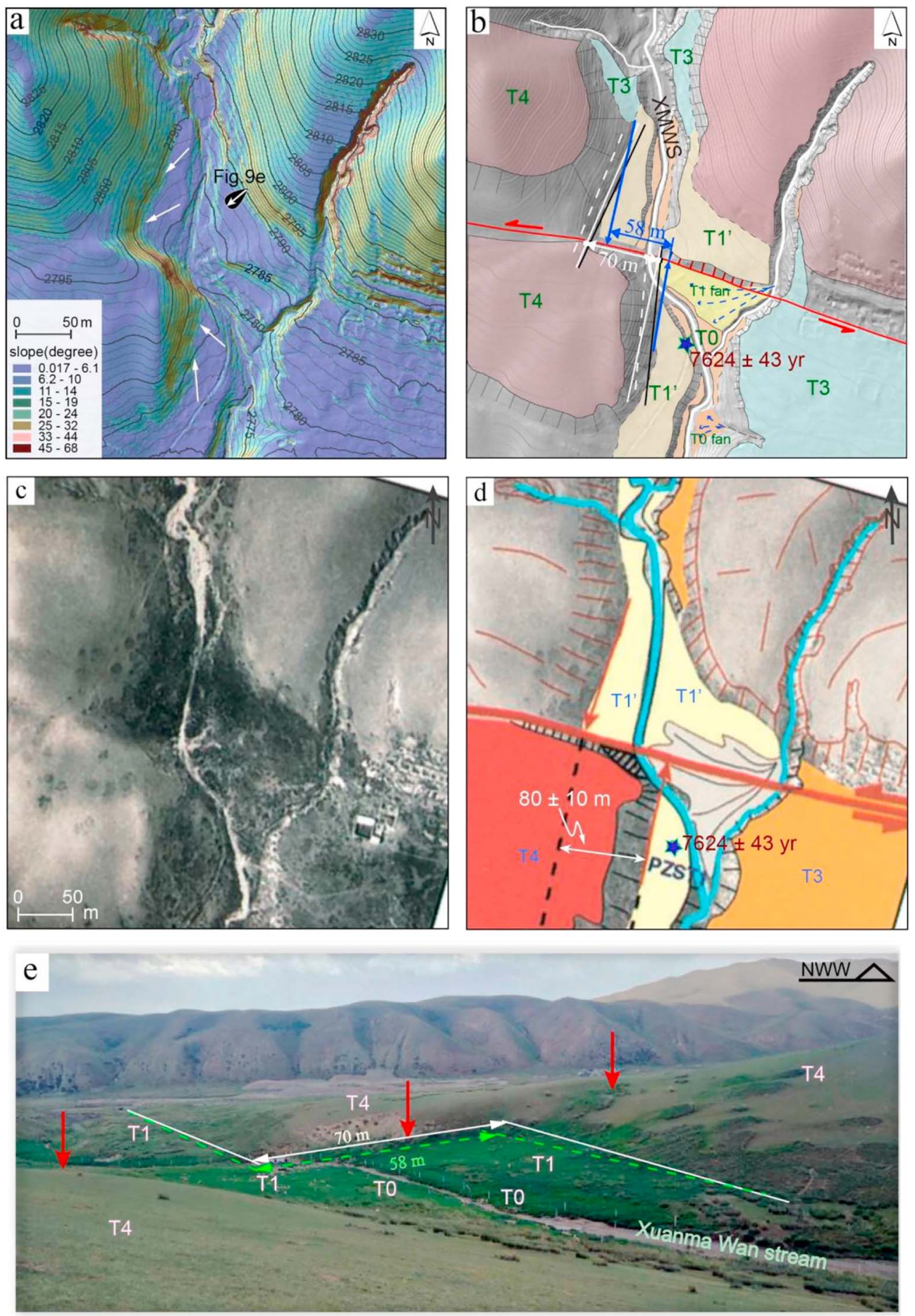

Figure 9. Displaced geomorphic features at the Xuanma Wan site. (a) Slope map with contour lines covering shaded relief map. (b) Geomorphic interpretation of the Xuanma Wan site. Also shown is the location of a ${ }^{14} \mathrm{C}$ charcoal sample of Lasserre et al. (1999). (c and d) H igh-resolution photograph and geomorphic map from Lasserre et al. (1999), respectively. (e) Field photo with SSW-looking view, incorporating geomorphic interpretation and offset measurements.

the two ${ }^{10} \mathrm{Be}$ samples from the upper gravel layer. Ages calculated for the lower gravel layer are $89.3 \pm 6.7$ and $87.0 \pm 6.9 \mathrm{ka}$. However, these ages do not account for the hiatus in deposition between layers, and the actual age of the lower gravel layer is likely greater than $100 \mathrm{ka}$. 

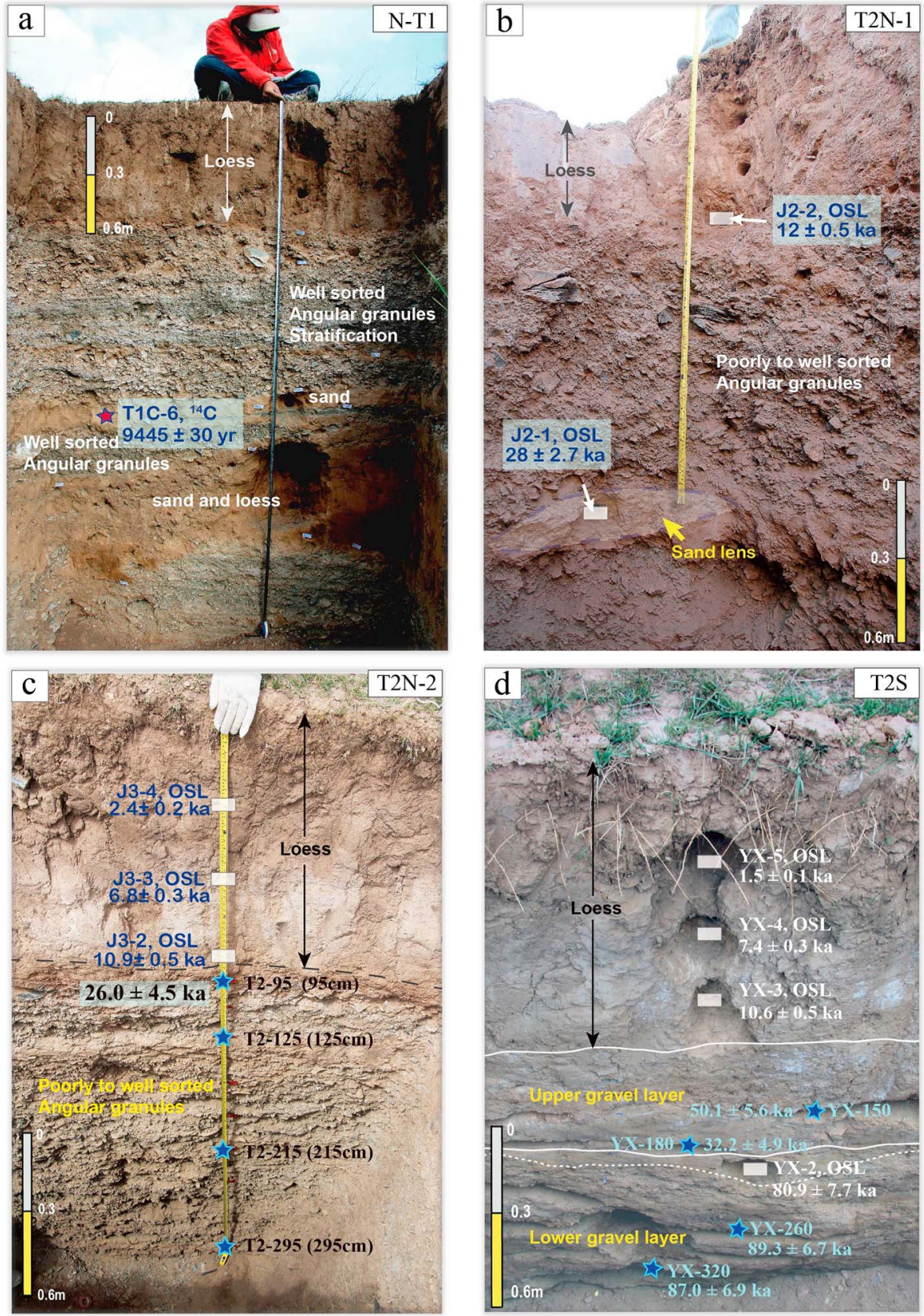

Figure 10. Photos of sampling of the Majia Wan site. (a) Photo with detailed stratigraphic observation and ${ }^{14} \mathrm{C}$ sampling in N-T1. (b) Photo with detailed stratigraphic observation and optically stimulated luminescence (OSL) sampling in T2N-1. (c) Field photo of T2N-2 sampling pit. (d) Photo with detailed stratigraphic observation and samples collected in T2S depth profiles. The red star marks the carbon-14 dating sample, whereas the blue stars and white rectangles indicate the ${ }^{10}$ Be samples and OSL samples, respectively.

\section{Results}

\subsection{Offset Determination}

At the Majia Wan site, several offset piercing lines can be matched across the Haiyuan fault, including the $\mathrm{T} 4 / \mathrm{T} 1$ riser on the west side of the Majia Wan stream and the crest and base of the T2/T1 riser on the east side of the stream (Figure 8a). We determined displacements by projecting the mapped crest and base of the $\mathrm{T} 2 / \mathrm{T} 1$ riser into the fault trace. To the north of the fault, the crest and the base of the T2/T1 riser is 
Table 4

Cosmogenic Age Determinations at the Majia Wan Site, Haiyuan Fault

\begin{tabular}{|c|c|c|c|c|c|c|}
\hline Trench & Sample ID & Depth $(\mathrm{cm})$ & $\begin{array}{c}{ }^{10} \text { Be concentration } \\
\left(10^{5} \text { atoms } / g\right)\end{array}$ & $\begin{array}{l}\text { Inheritance } \\
\left(10^{5} \text { atoms } / g\right)\end{array}$ & $\begin{array}{c}\text { Loess } \\
\text { thickness, }(\mathrm{cm})\end{array}$ & Age (ka) \\
\hline \multirow[t]{4}{*}{$\mathrm{T} 2 \mathrm{~N}-2$} & T3-95 & 95 & 9.43 & $5.14 \pm 0.34$ & 90 & $26.0 \pm 4.5$ \\
\hline & T3-125 & 125 & 7.66 & & & \\
\hline & T3-215 & 215 & 6.70 & & & \\
\hline & T3-295 & 295 & 5.06 & & & \\
\hline \multirow[t]{4}{*}{$\mathrm{T} 2 \mathrm{~S}$} & YX-150 & 150 & 10.01 & - & 120 & $50.1 \pm 5.6$ \\
\hline & YX-180 & 180 & 4.52 & & & $32.2 \pm 4.9$ \\
\hline & YX-260 & 260 & 4.70 & & & $89.3 \pm 6.7$ \\
\hline & YX-320 & 320 & 2.16 & & & $87.0 \pm 6.9$ \\
\hline
\end{tabular}

linear and well defined, although the base of the riser shows a small curved segment approaching to the fault, which contributes a small amount to the uncertainty in measurement of displacement. Main uncertainty comes from the identification of the riser-fault intersection to the south of the fault, due to its gentle slope and heavy modification.

Reconstruction of offset by backslipping shows that the crest of the T2/T1 riser is offset by 127 and $134 \mathrm{~m}$ based on the near-field and far-field projection, respectively (Figures 11a and 11b). Combining both of the displacement values and the above-mentioned uncertainty, the crest of the T2/T1 riser is offset by $130 \pm$ $10 \mathrm{~m}$. Meanwhile, the T4/T1 riser on the west side the stream appears to also be offset by $130 \pm 10 \mathrm{~m}$, which basically confirms the estimate of $125 \pm 10 \mathrm{~m}$ of the same feature by Lasserre et al. (1999; Figure $8 \mathrm{~b}$ ). On the other hand, the back slip of the base of this riser gives the best estimate of the offset to be $93 \mathrm{~m}$ (bb' in Figure 11c). An upper bound of this offset is constrained by the location of the T2S pit south of the fault. The dating from the T2S pit confirms that it is not covered by the Holocene T1 terrace fills. Thus, the base of the T2/T1 riser should be to the west of the T2S pit. Projecting the position of the T2 pit to the fault (bb " in Figure 11c) would yield the upper bound of $108 \mathrm{~m}$, which also indicates the uncertainty on the order of $15 \mathrm{~m}$. Collectively, the offset of the base of the T2/T1 riser is $93 \pm 15 \mathrm{~m}$.

At the Xuanma Wan site, our mapping is similar to that by Lasserre et al. (1999; Figures 9b, 9d, and 9e), except that our projection of the base of the $\mathrm{T} 4 / \mathrm{T}^{\prime}$ - riser to the Haiyuan fault differs. We determined a maximum displacement for this riser of $67 \mathrm{~m}$ using a near-fault projection. If instead we project the base of the $\mathrm{T} 4 / \mathrm{T} 1^{\prime}$ from the far-field, the offset may be as small as $58 \mathrm{~m}$ (Figures $9 \mathrm{~b}$ and $9 \mathrm{e}$ ). If the method in Stewart et al. (2018) is used, the base of T4/T1' riser is offset by $68.0 \pm 2.4 \mathrm{~m}$ (black lines in Figures $9 \mathrm{~b}$ and 12a), which is similar to the upper bound of our back slip estimate. The difference is mainly due to the distance to over which the marker is projected to the fault, which are defined as far-field and near-field on account of the geometry of the terrace riser extending from the fault zone. Again, using the method by Stewart et al. (2018), the middle and the top of $\mathrm{T} 4 / \mathrm{T}^{\prime}$ is offset by $70 \pm 1.1 \mathrm{~m}$ and $70 \pm 1.5 \mathrm{~m}$, respectively (white lines and dashed lines in Figures $9 \mathrm{~b}$ and $12 \mathrm{~b}$ and $12 \mathrm{c}$ ). Combining all different scenarios and reconstruction of offset by back slip, the best estimate of the offset is determined to be $68^{+3} /-10 \mathrm{~m}$ (Figure 13). This estimate is less than but within the low end of $80 \pm 10 \mathrm{~m}$ measured by Lasserre et al. (1999), which was based on optical images (DEM was not yielded at the time, due to an erratic flight of the plane acquiring air photos, Lasserre et al. (1999).

\subsection{Age Determination of $\mathrm{T} 2$}

We estimate the age of abandonment of $\mathrm{T} 2$ as $26.0 \pm 4.5 \mathrm{ka}$ from the combined analysis of ${ }^{10} \mathrm{Be}$ and OSL samples from T2N-2. This age is consistent with the OSL date of $28.0 \pm 2.7$ ka from T2 sediments in T2N-1 and also consistent with the more limited age information from pit T2S, which loosely brackets $\mathrm{T} 2$ between the $15.4 \mathrm{ka}$ loess contact age and the $32.2 \pm 4.9 \mathrm{ka}{ }^{10} \mathrm{Be}$ age for sample YX-180, uncorrected for inheritance.

\subsection{Slip Rate Determination}

Riser displacement caused by successive strike-slip earthquakes starts to be recorded sometime between the abandonment of the upper and lower treads. Cowgill (2007) discussed the impact of the lower-terrace and upper-terrace reconstruction scenario in slip rate calculation in detail and proposed six geomorphic indices assisting to identify the accurate reconstruction of fluvial risers. The lower-terrace 

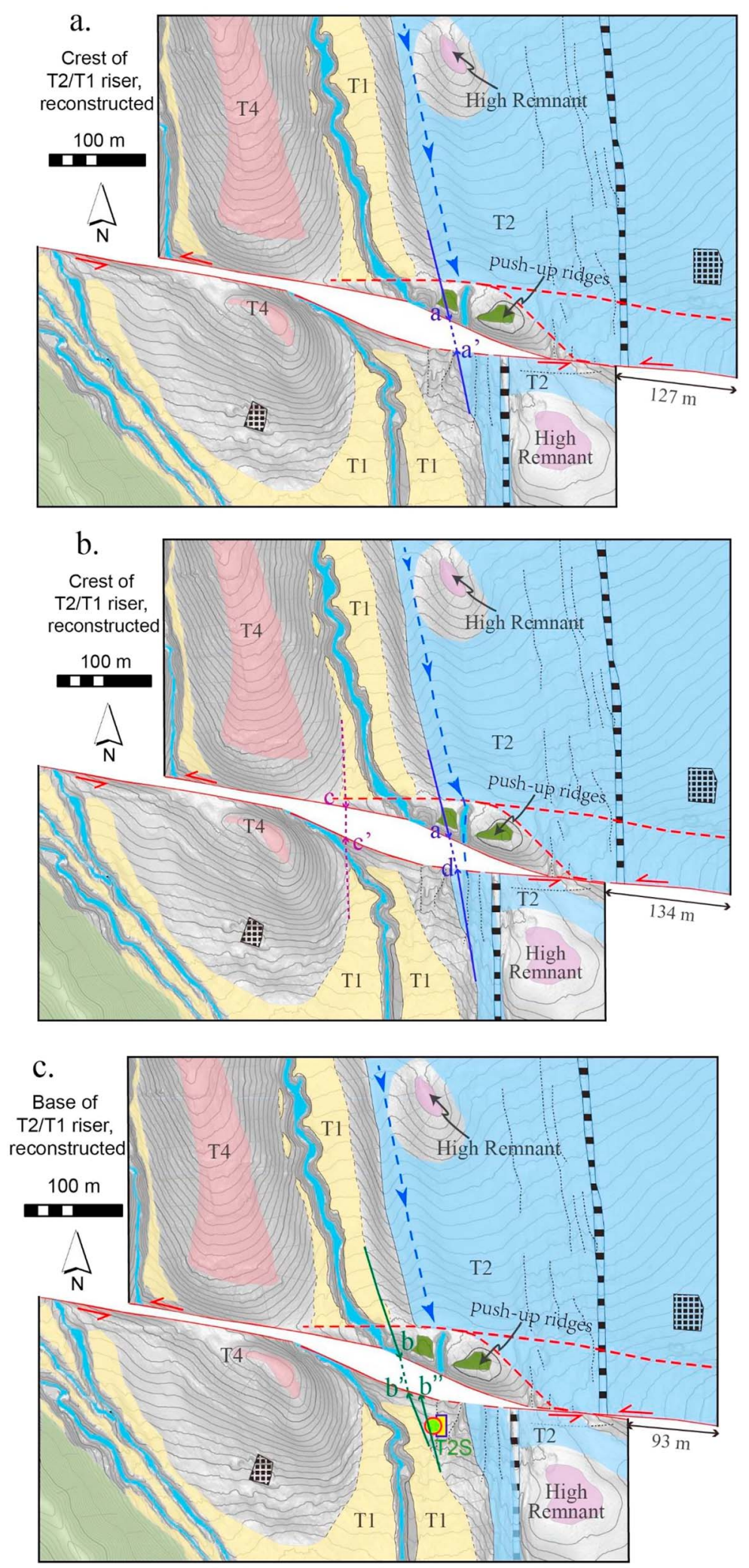

Figure 11. Offset reconstruction of the crest (a, b) and base (c) of the T2/T1 riser on the left bank of the Majia Wan stream. (a) Near field and (b) far field projection of the crest of T2/T1 riser yield offset of 127 and $134 \mathrm{~m}$, respectively. (c) Near-field projection of the base of T2/T1 riser south of the fault suggests an optimal offset of $93 \mathrm{~m}$. Note that the upstream and downstream piercing lines can match each other preoffset that can be used as the surface markers. 


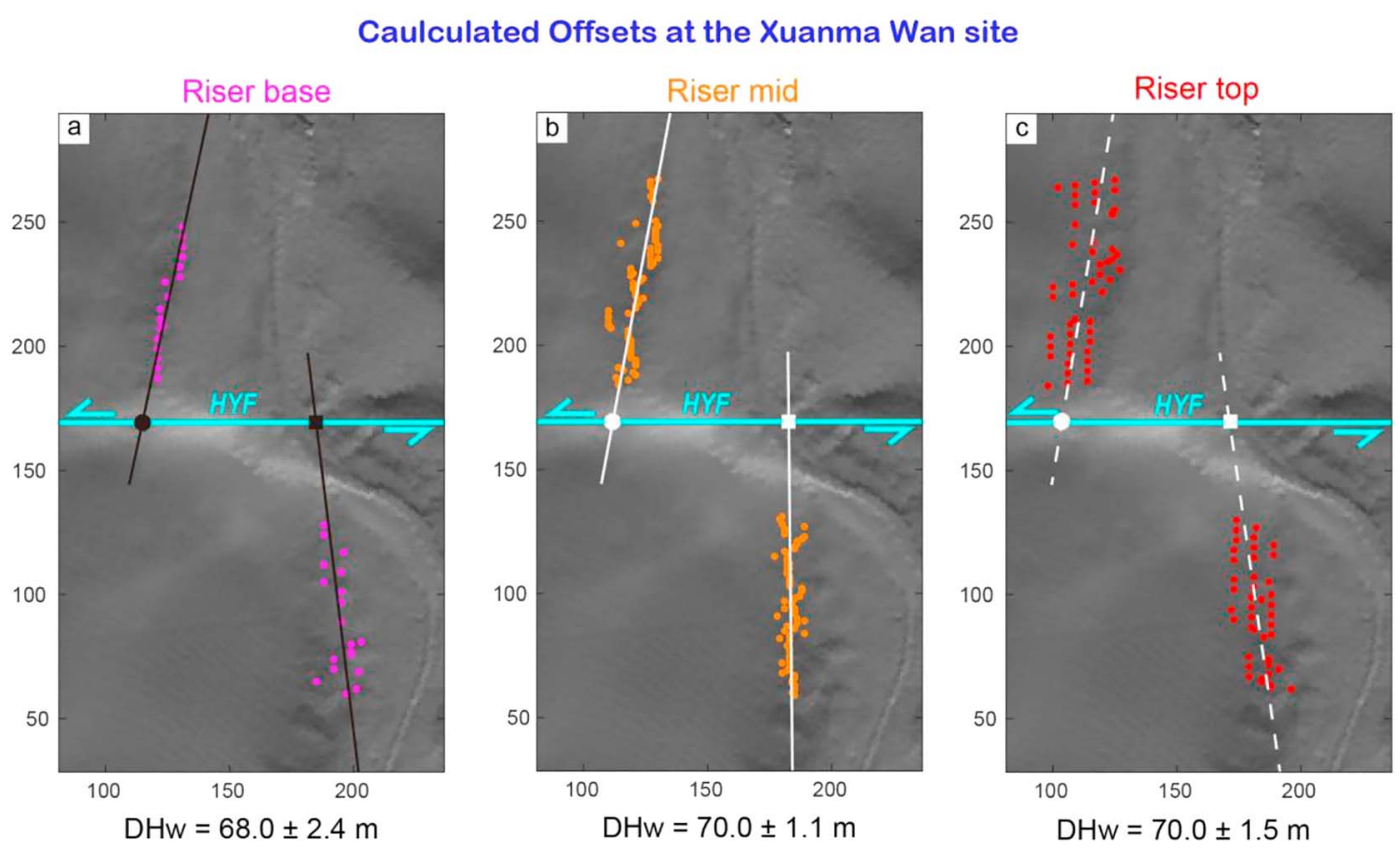

Figure 12. Delineation of various terrace features and their offsets at the Xuanma Wan site by the method in Stewart et al. (2018).

reconstruction model yields a maximum slip rate by assuming that stream flow on the lower tread always has enough power to completely erode and refresh the riser such that offset does not begin to accrue until the lower surface is abandoned. In contrast, the upper-terrace reconstruction model provides a minimum slip rate based on the assumption that the flow over the lower terrace is too weak to refresh the riser. Therefore, the riser offset would start accruing as soon as the riser forms by incision of the upper tread (Cowgill, 2007).

At the Majia Wan site, dividing the cumulative displacement of the crest of the T2/T1 riser (130 $\pm 10 \mathrm{~m})$ by the minimum abandonment age of the T2 tread $(26.0 \pm 4.5 \mathrm{ka})$ yields a minimum left-lateral slip rate of $5.0^{+1.5} /-1.1 \mathrm{~mm} /$ year (Figure 14). If we use the lower terrace reconstruction scenario, the cumulative displacement of the base of the T2/T1 riser $(93 \pm 15 \mathrm{~m})$ and the abandonment age of the T1 tread $(9,445 \pm 30$ year $)$ would yield a maximum slip rate of $9.8 \pm 1.6 \mathrm{~mm} /$ year. This is less than the estimate of $12.7 \pm 1.2 \mathrm{~mm} /$ year in Lasserre et al. (1999), which used the T4/T1 riser on the west bank $(125 \pm 10 \mathrm{~m})$ as the offset marker and the age of $\mathrm{T} 1$ terrace $(9,867 \pm 164$ year $)$ as the offset age. Hence, their optimal estimate of $\sim 12.7 \mathrm{~mm} /$ year is equivalent to the lower terrace reconstruction (T2 age) scenario to provide a lower bound of $8 \mathrm{~mm} / \mathrm{year}$ on the slip rate. However, the sample they dated was from the loess cover ( $14 \mathrm{ka})$ on T2 remnant within the fault zone and thus considerably younger than the abandonment of T2 surface ( $26 \mathrm{ka})$.

At Xuanma Wan site, Lasserre et al. (1999) also adopted the lower terrace reconstruction in calculating the slip rate, using the offset of the base of the $\mathrm{T} 4 / \mathrm{T} 1^{\prime}$ riser on the western bank $(80 \pm 10 \mathrm{~m})$ and abandonment age of $\mathrm{T} 1{ }^{\prime}\left({ }^{14} \mathrm{C} 7,624 \pm 43\right.$ year, Table 1$)$. Our updated measurement of the T4/T1 riser offset, thanks to new high-resolution DEM data (the same line mark as the T4/T1 ${ }^{\prime}$ riser in Lasserre et al. (1999)), is only $68^{+3} /{ }_{-10}$ $\mathrm{m}$. Dividing the cumulative displacement of the $\mathrm{T} 4 / \mathrm{T} 1^{\prime}$ riser $\left(68^{+3} /-10 \mathrm{~m}\right)$ by the abandonment age of the $\mathrm{T} 1^{\prime}$ tread $\left(7,624 \pm 43\right.$ year) yields an upper bound slip rate of $8.9^{+0.5} /{ }_{-1.3} \mathrm{~mm} /$ year (Figure 14). Since $\mathrm{T} 1^{\prime}$ terraces in the Majia Wan site are generally fill terraces, the abandonment of the lower terrace is likely to be younger than the initiation of offset accruement, and $8.9^{+0.5} /{ }_{-1.3} \mathrm{~mm} /$ year is very likely to be an overestimation of the true fault slip rate. We also note that this lower terrace bound is slightly lower than the same bound of slip rate of $9.8 \pm 1.6 \mathrm{~mm} /$ year at Majia Wan site using a lower terrace reconstruction. Therefore, we consider the slip rate of $8.9^{+0.5} /-1.3 \mathrm{~mm} /$ year as the upper bound. By combing the upper bound $\left(8.9^{+0.5} /-1.3\right.$ $\mathrm{mm} /$ year) and the lower bound $\left(5.0^{+1.5} /{ }_{-1.1} \mathrm{~mm} /\right.$ year $)$ determined from this study, the average late Pleistocene slip rate of the Haiyuan fault along the Laohu Shan section is between 5.0 and 8.9 $\mathrm{mm}$ /year (Figure 14). 

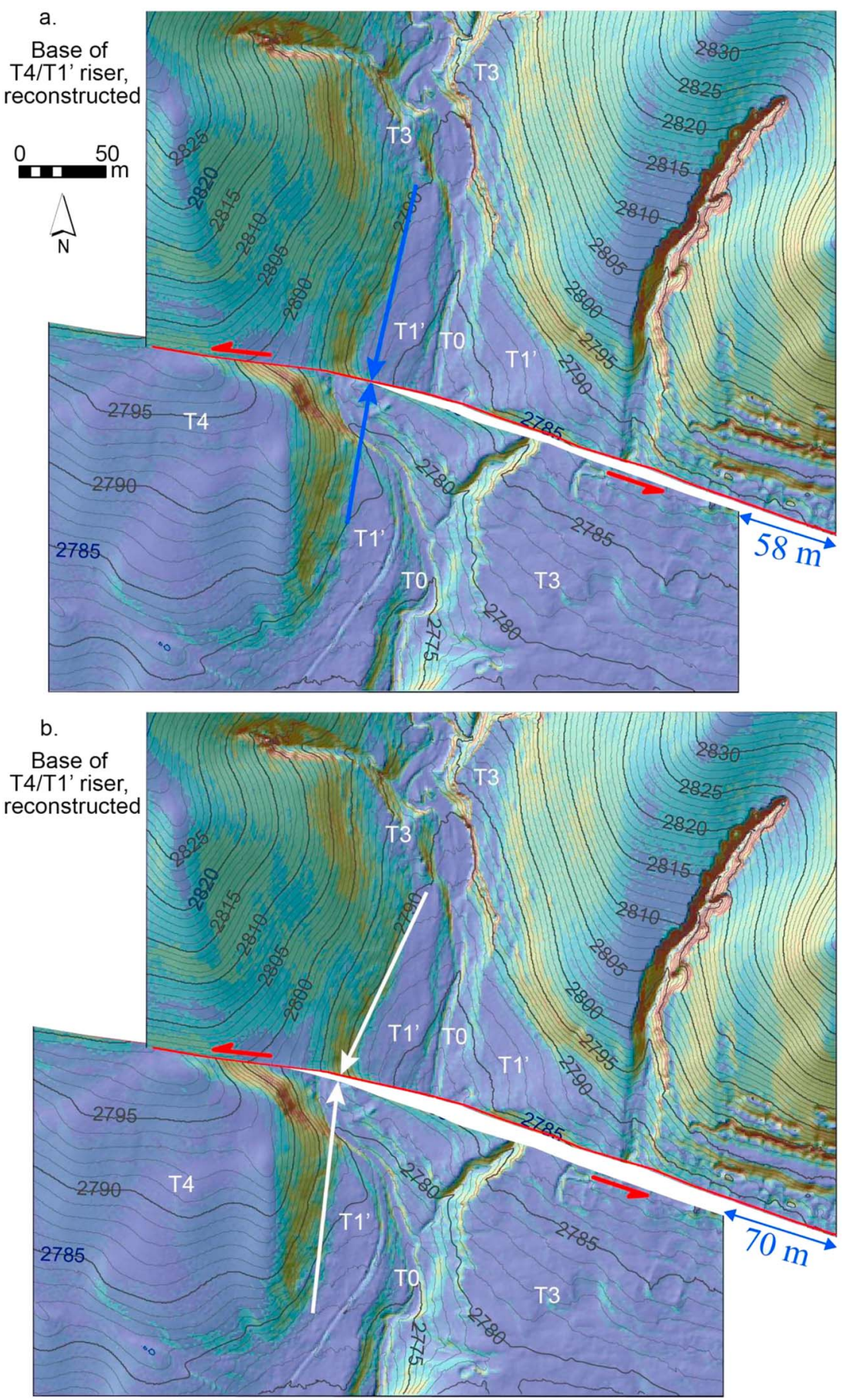

Figure 13. Reconstruction showing offset measurements of the base of $\mathrm{T} 4 / \mathrm{T} 1^{\prime}$ riser, (a) the lower bound of $58 \mathrm{~m}$ by a farfield fault-perpendicular line projection and (b) the upper bound of $70 \mathrm{~m}$ by the method in Stewart et al. (2018).

\section{Discussion}

\subsection{The Upper Terrace Versus Lower Terrace Reconstruction}

The shape and offsets of the T2/T1 riser and T4/T1 riser at the Majia Wan site suggest incomplete riser refreshment. Left-lateral faulting moved the left-bank riser away from the channel, usually making it less susceptible to incision (sheltered corner; Figures 15a and 15b). Indeed, the T2/T1 riser on the east bank slopes gently toward the active channel on the downstream side of the fault, suggesting a gradual 


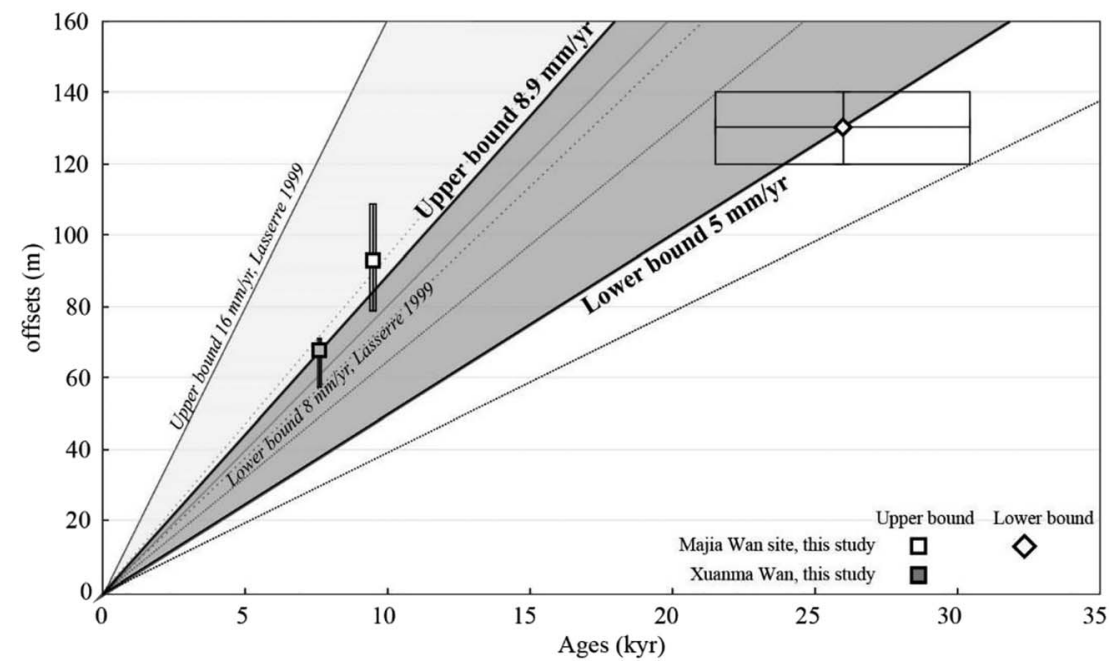

Figure 14. Slip rate estimates from the offset and age data. Combining the slip rates of both sites thus determines a leftlateral slip rate in the range of 5.0-8.9 mm/year, along the Laohu Shan section of the Haiyuan fault since $\sim 26 \mathrm{ka}$. Note that the light grey shaded zone indicates the lower and upper bound rate of $11 \pm 4$ and $12 \pm 4 \mathrm{~mm}$ /year studied by Lasserre et al. (1999).

downcutting as offset accrued (Figure 15c). T1 filled in against this feature, and as a consequence, the base of the T2/T1 riser is offset less than its crest. The T4/T1 terrace riser on the west bank also accrued left-lateral offset before the abandonment of T1 (Figures 15d and 15e). This riser occupies an unprotected position, moving in front of Majia Wan stream as offset accrued. This further reinforces that streamflow was insufficient to completely refresh the risers adjacent to the stream, supporting our upper terrace age interpretation. In addition, the active channel shows a left-lateral dogleg bending with a similar amount of apparent offset $(\sim 100 \mathrm{~m})$ if projected from far on both sides. These observations together indicate consistently that the Majia Wan stream must be too weak to incise vigorously since the abandonment of the T2 surface.

A key interpretation in our re-examination of the Majia Wan site is that the T2/T1 riser started to accrue the offset some time after the abandonment of the upper terrace T2 and before the formation of T1. Our

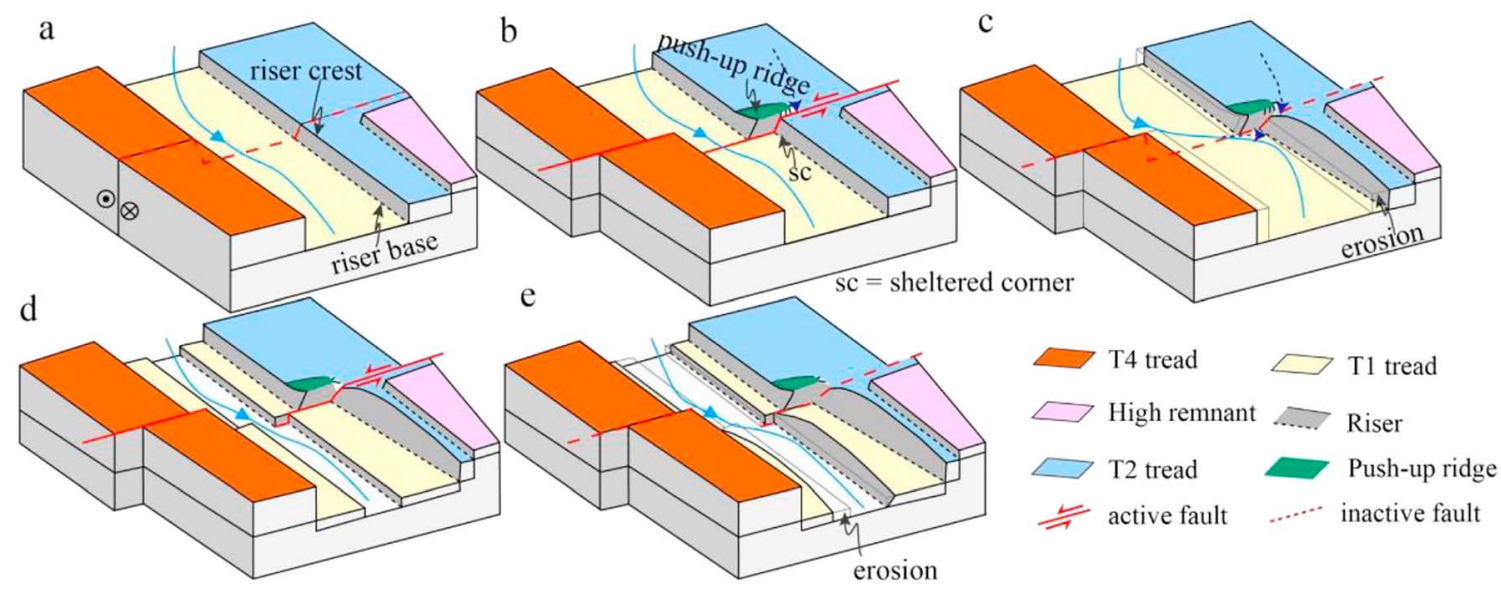

Figure 15. Schematic diagrams showing our preferred evolution of morphotectonics at the Majia Wan site. We set the time when the T2 tread was abandoned as the beginning of our story. After T2 was abandoned (a), the Haiyuan fault offset T4 and T2 and the push-up ridge was formed (b), following the incomplete $\mathrm{T} 2 / \mathrm{T} 1$ refreshment, which cause the southern $\mathrm{T} 2 / \mathrm{T} 1$ riser to gentle slope toward the active channel (c), which supports the upper-terrace reconstruction (Cowgill, 2007). Then the incision and offset of the floodplain to abandon the tread of T1 (d). Later, due to subsequent slip of the Haiyuan fault, the base and crest of the T2/T1 riser accumulate unequal displacement, and the T4/T1 riser on the west bank of the Majia Wan stream accrued displacement (e). Based on this model, we believe that the T2/T1 riser is more credible to document the offset at the Majia Wan site. 
reevaluation of the two sites from Lasserre et al. (1999) highlights the effect of the assumption of the upperterrace or lower-terrace ages for the onset of offset accumulation. Our observations thus do not support the assumption of the lower-terrace reconstruction in previous slip rate calculations in Lasserre et al. (1999), which likely overestimated the slip rate by a factor of 2 . This is similar to the Cherchen river site on the Altyn Tagh fault by Mériaux et al. (2004), as shown by Cowgill (2007). The lower terrace age for offset on the Kunlun fault, on the other hand, has a smaller effect on its slip rate estimate because the upper terrace is close in age (Li et al., 2005; van der Woerd et al., 1998, 2002).

It is not well understood why the lower-terrace reconstruction sometimes is an appropriate assumption and sometimes is not. Globally, there are cases showing that riser offset follows the lower-terrace reconstruction, for instance, on the San Andreas fault in California (Weldon \& Sieh, 1985), or the Wairarapa fault and the Wellington fault in New Zealand (Berryman, 1990; Carne et al., 2011). The key factor may be the competition between how fast the fault moves and lateral erosion during the formation of the lower terrace tread (Cowgill, 2007; Mériaux et al., 2005; Ouchi, 2004, 2005). The ability of the river to incise laterally or vertically is affected by regional climate, sediment supply, tectonic forcing, and river gradient (e.g., Hancock \& Anderson, 2002; Lague et al., 2005; Malatesta et al., 2018; Poisson \& Avouac, 2004). In New Zealand, the drainages producing offset risers are generally large, permanent rivers, which are powerful enough to frequently refresh their banks. Whereas in northern Tibet, the semiarid climate condition leads to ephemeral river channels that incise only during infrequent strong storms and have lower power to refresh their banks. Specifically, at the Majia Wan site, the small and ephemeral river channel is dry most of the time. Where it crosses the fault, the river is $0.8 \mathrm{~km}$ downstream from the mountain front and has a very low gradient of 0.0449 .

\subsection{Slip Rate at Various Time Scales}

It has been suggested that large strike-slip fault systems may exhibit rate fluctuations over geologic and geodetic time scales (Chevalier et al., 2005; Rittase et al., 2014), which have prompted controversy concerning whether disparate slip rate measurements indicate secular variation in slip for the major strike-slip faults of the Tibetan Plateau. Secular variation in fault slip may be associated with earthquake clusters (Rockwell et al., 2000; Wechsler et al., 2017) or due to variations in fault zone mechanics and measurement interval (Chevalier et al., 2005). However, there are also works suggesting that the difference of rate for strike-slip faults over different time scales are not significant (Meade et al., 2013).

Our best estimate of left-lateral slip rate along the Laohu Shan section of the Haiyuan fault is 5.0-8.9 $\mathrm{mm}$ /year since $\sim 26 \mathrm{ka}$. The lower bound of this geologic slip rate over the last 26,000 year is similar to geodetically inferred strain accumulation rates of 4-7 mm/year along the same segment of the fault (Cavalié et al., 2008; Daout et al., 2016; Gan et al., 2007; Wang et al., 2017). From a regional perspective, the extensive measurements presently available imply that the average slip rate of the main part of the Haiyuan fault is 7.0 $\pm 2.0 \mathrm{~mm}$ /year, with no evidence of Latest Quaternary secular variation (Figure 16a). Other studies have documented consistent slip rates over multiple time scales, as we have here (Blisniuk et al., 2013; Cowgill et al., 2009; Gold et al., 2009; Grove \& Niemi, 2005; Le Beon et al., 2008, 2012; Toké et al., 2011). In terms of lateral variation, excluding earlier studies of Zhang et al. (1988), He et al. (1994), and Yuan et al. (1998), which lacked rigorous geochronological constraints, the horizontal slip rate along the Haiyuan fault appears to slightly decrease eastward from Jinqiang He section to that broken in the 1920 Haiyuan earthquake.

\subsection{Implication for Block Models of Deformation}

How fast the active strike-slip faults in Tibet move is an important topic, as it provides basic data in evaluating end-member kinematic models for deformation of the Tibet plateau. Block models suggest that most deformation occurs along major block-bounding faults, with little internal deformation of the blocks. Continuum models, at the opposite extreme, imply that slip occurs on many fault with roughly comparable slip rates. Reassessment of the slip rate sites of Lasserre et al. (1999) shows that the left-lateral slip rate on the Haiyuan fault is about half of that previously reported. A similar situation exists about the slip rate of the Altyn Tagh fault (e.g., Cowgill et al., 2009; Mériaux et al., 2004, 2005; Zhang et al., 2007). Since in early studies high slip rates (10-30 mm/year) on major strike slip faults were used to constrain block models (e.g., Avouac \& Tapponnier, 1993), it led to the implicit assumption that the block models would fail if the fault 

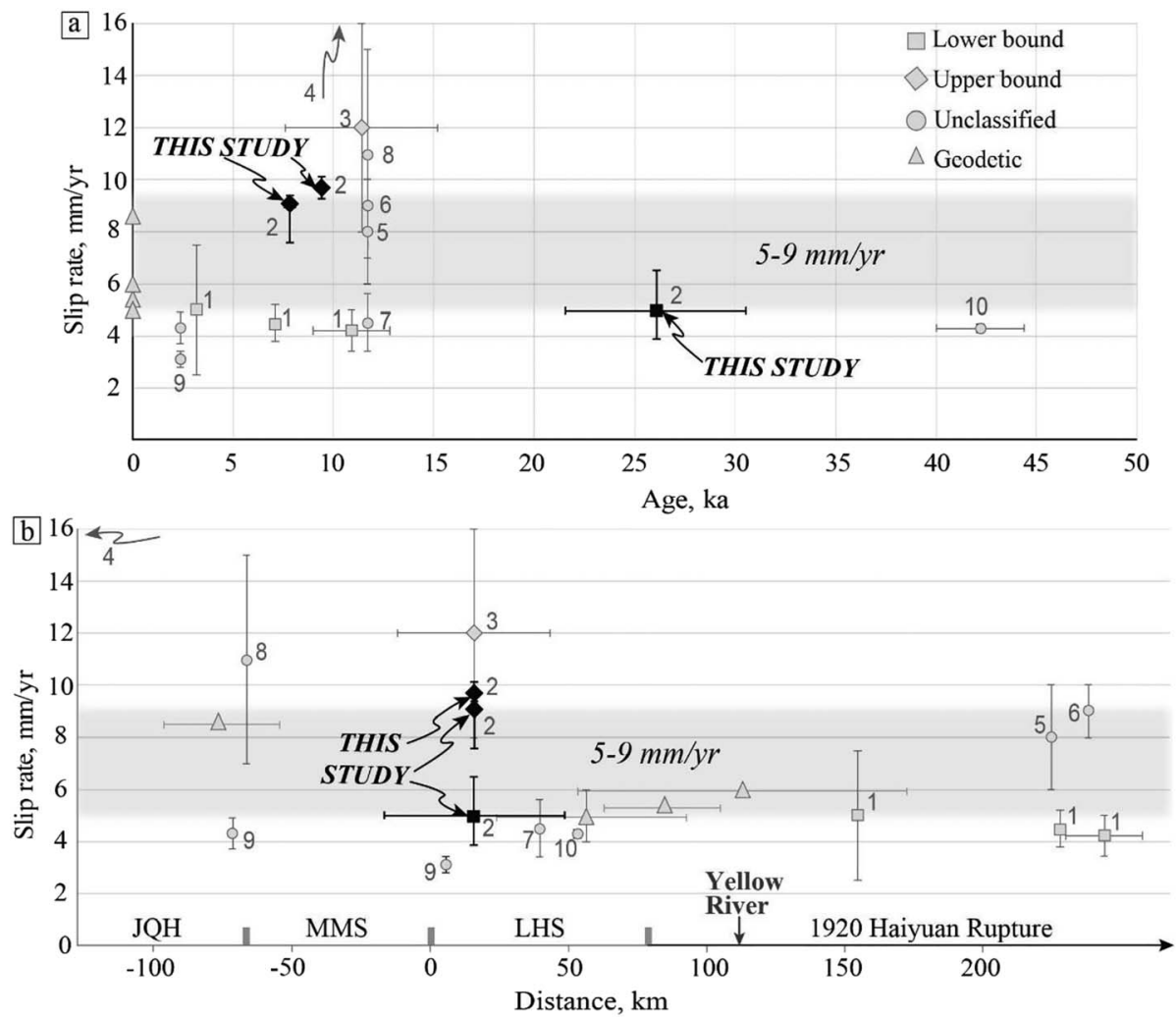

Figure 16. Summary of slip rates along the Haiyuan fault at diverse time scales (a) and at different locations along the fault (b). Squares denote upper-terrace constrained slip rates by Li et al. (2009) (1) and this study (2). Diamonds indicate slip rates based on a lower-terrace reconstruction by Lasserre et al. (1999) (3) and Lasserre et al. (2002) (4). Circles denote those without specification of geochronological constraints by Zhang et al. (1988) (5), Burchfiel et al. (1991) (6), He et al. (1994) (7), Gaudemer et al. (1995) (8), Yuan et al. (1998) (9), and Liu et al. (2018) (10). Triangles are geodetic rates from Cavalié et al. (2008), Jolivet et al. (2013), and Daout et al. (2016). Error bar for interferometric synthetic aperture radar (InSAR)-derived geodetic rate represent the width of InSAR tracks. The horizontal bar with gray shading indicate a reasonable uniform slip rate of 5-9 mm/year over multiple time scales and along strike of the Haiyuan fault. JQH = Jinqiang He; MMS = Mao Mao Shan; LSH = Lao Hu Shan.

slip rates were significantly less than the previously determined high geological estimates. Indeed, low slip rates estimated from geodesy have been used to argue that continuum models are more appropriate (e.g., Wright et al., 2004; Zhang et al., 2004). However, studies show that quasi-rigid block models provide a first-order description of GPS velocity field of Tibet and predict low slip rates on the block bounding faults in northern Tibet (Meade, 2007; Thatcher, 2007; Wang et al., 2017). Updated estimates of geologic slip rates on major strike-slip faults in northern Tibet are similar to those predicted by GPS data and block models, within the uncertainty of each method. The generally good agreement between geologically observed and GPS predicted rates and style suggests that relative block motions described by present-day deformation have been sustained over a geological time scale. Collecting more well-constrained fault slip rate data across a system of faults in Tibet would help to evaluate whether intrablock deformation is as important as slip on major faults, by showing strain accommodation by a small number of major faults or by a fault population without as much distinction of major and minor faults.

\section{Conclusions}

The high-resolution DEMs generated from airborne LiDAR along the Haiyuan fault provide a valuable opportunity to interpret details of microtopographic features useful for slip rate evaluation. We apply these data in conjunction with detailed field mapping and additional geochronology to reinterpret two sites originally described by Lasserre et al. (1999). The abandonment ages of terraces have been determined through a combination of ${ }^{10} \mathrm{Be}$, OSL, and ${ }^{14} \mathrm{C}$ dating methods. The configuration of serial offset piercing lines suggests 
an upper-terrace abandonment age scenario better clocks the accrual of slip for the offset T1/T2 riser at Majia Wan stream. We find that the Haiyuan fault has accrued $130 \pm 10 \mathrm{~m}$ of offset since the abandonment of T2 at $26.0 \pm 4.5 \mathrm{ka}$, which yields an average left-lateral slip rate of $5.0^{+1.5} /{ }_{-1.1} \mathrm{~mm} /$ year. A lower-terrace age constraint yields an upper bound of slip rate of $9.8 \pm 1.6 \mathrm{~mm} /$ year by using the T2/T1 riser and the age of T1 abandonment. This is smaller than the original study by Lasserre et al. (1999) that also used a lower terrace age constraint. An upper bound in slip rate of $8.9^{+0.5} /-1.3 \mathrm{~mm} /$ year is suggested by the lower terrace reconstruction at the Xuanma Wan site. Our reevaluation of the sites in Lasserre et al. (1999) highlights the effect of the assumption of the upper-terrace or lower-terrace ages for the onset of offset accumulation. Apparent slip rate discrepancies in northern Tibet possibly share a common bias due to a systematic application of a lower-terrace reconstruction to interpret the age of offset.

\section{Acknowledgments}

Detailed and constructive comments by three reviewers (Cecile Lasserre, Michael Taylor and Associate Editor Alexander Webb) greatly helped improve the quality of this work. This project was conducted under the auspices of the National Natural Science Foundation of China (41761144065, U1839203, and 41802228) and the State Key Laboratory of Earthquake Dynamics of China (LED2017A01 and LED2016A02). Part of the work with Yann Klinger is supported through the CNRS PICS FranceChine program. We thank Huili Yang and Changsheng Wang for assistance with OSL samples. We also thank Tang Maoyun and Han Longfei for the fieldwork. Zhang Huiping and Yang Haibo are thanked for providing help and advice in the process of geochronology data. The data used are listed in the tables and supporting information.

\section{References}

Anderson, R. S., Repka, J. L., \& Dick, G. S. (1996). Explicit treatment of inheritance in dating depositional surfaces using in situ ${ }^{10}$ Be and ${ }^{26} \mathrm{Al}$. Geology, 24(1), 47-51. https://doi.org/10.1130/0091-7613(1996)0242.3.CO

Avouac, J. P., \& Tapponnier, P. (1993). Kinematic model of active deformation in central Asia. Geophysical Research Letters, 20(10), 895-898. https://doi.org/10.1029/93GL00128

Bai, M., Chevalier, M.-L., Pan, J., Replumaz, A., Leloup, P. H., Métois, M., \& Li, H. (2018). Southeastward increase of the late Quaternary slip-rate of the Xianshuihe fault, eastern Tibet. Geodynamic and seismic hazard implications. Earth and Planetary Science Letters, 485, 19-31. https://doi.org/10.1016/j.epsl.2017.12.045

Balco, G. (2006). Converting Al and Be isotope ratio measurements to nuclide concentrations in quartz. Documentation-Be-10/26-Al exposure age calculator.

Berryman, K. (1990). Late Quaternary movement on the Wellington Fault in the Upper Hutt area, New Zealand, New Zealand. Journal of Geology and Geophysics, 33(2), 257-270. https://doi.org/10.1080/00288306.1990.10425683

Blisniuk, K., Oskin, M., Mériaux, A.-S., Rockwell, T., Finkel, R. C., \& Ryerson, F. J. (2013). Stable, rapid rate of slip since inception of the San Jacinto fault, California. Geophysical Research Letters, 40, 4209-4213. https://doi.org/10.1002/grl.50819

Braucher, R., Merchel, S., Borgomano, J., \& Bourlès, D. (2011). Production of cosmogenic radionuclides at great depth: A multi element approach. Earth and Planetary Science Letters, 309(1-2), 1-9. https://doi.org/10.1016/j.epsl.2011.06.036

Burchfiel, B. C., Zhang, P., Wang, Y., Zhang, W., Song, F., Deng, Q., et al. (1991). Geology of the Haiyuan fault zone, Ningxia-Hui Autonomous Region, China, and its relation to the evolution of the northeastern margin of the Tibetan Plateau. Tectonics, 10(6), 1091-1110. https://doi.org/10.1029/90TC02685

Cai, S. H., Hou, Z. Q., Jia, Y. H., \& Hou, K. M. (1992). Discussion on the intensity and seismic structure of the Tianzhu 6.2 earthquake in Gansu Province in 1990 [in Chinese]. China Earthquake Engineering Journal, (1), 28-32.

Carne, R. C., Little, T. A., \& Rieser, U. (2011). Using displaced river terraces to determine Late Quaternary slip rate for the central Wairarapa Fault at Waiohine River, New Zealand. New Zealand Journal of Geology and Geophysics, 54(2), 217-236. https://doi.org/ $10.1080 / 00288306.2010 .532224$

Cavalié, O., Lasserre, C., Doin, M. P., Peltzer, G., Sun, J., Xu, X., \& Shen, Z. K. (2008). Measurement of interseismic strain across the Haiyuan fault (Gansu, China), by InSAR. Earth and Planetary Science Letters, 275(3-4), 246-257. https://doi.org/10.1016/j. epsl.2008.07.057

Chen, T., Liu-Zeng, J., Shao, Y., Zhang, P., Oskin, M. E., Lei, Q., \& Li, Z. (2018). Geomorphic offsets along the creeping Laohu Shan section of the Haiyuan fault, northern Tibetan Plateau. Geosphere, 14(3), 1165-1186. https://doi.org/10.1130/GES01561.1

Chen, T., Zhang, P. Z., Liu, J., Li, C. Y., Ren, Z. K., \& Hudnut, K. W. (2014). Quantitative study of tectonic geomorphology along Haiyuan fault based on airborne LiDAR [in Chinese]. Chinese Science Bulletin, 59(20), 2396-2409. https://doi.org/10.1007/s11434014-0199-4

Chéry, J., \& Vernant, P. (2006). Lithospheric elasticity promotes episodic fault activity. Earth and Planetary Science Letters, 243(1-2), 211-217. https://doi.org/10.1016/j.epsl.2005.12.014

Chevalier, M. L., Leloup, P. H., Replumaz, A., Pan, J., Liu, D., Li, H., et al. (2016). Tectonic-geomorphology of the Litang fault system, SE Tibetan Plateau, and implication for regional seismic hazard. Tectonophysics, 682, 278-292. https://doi.org/10.1016/j. tecto.2016.05.039

Chevalier, M.-L., Ryerson, F., Tapponnier, P., Finkel, R., van der Woerd, J., Li, H. B., \& Qing, L. (2005). Slip-rate measurements on the Karakorum fault may imply secular variations in fault motion. Science, 307(5708), 411-414. https://doi.org/10.1126/science.1105466

Chiba, T., Kaneta, S. I., \& Suzuki, Y. (2008). Red relief image map: New visualization method for three dimensional data. The International Archives of the Photogrammetry, Remote Sensing and Spatial Information Sciences, 37(B2), 1071-1076.

Committee for Chinese Earthquake Bulletin (1990). The October 20, 1990 Ms 6.2 Tianzhu—Jintai, Gansu earthquake [in Chinese]. In Chinese Earthquake Yearly Bulletin, 1990, (pp. 167-171). Beijing: Seismological Publishing House.

Cowgill, E. (2007). Impact of riser reconstructions on estimation of secular variation in rates of strike-slip faulting. Revisiting the Cherchen River site along the Altyn Tagh Fault, NW China. Earth and Planetary Science Letters, 254(3-4), 239-255. https://doi.org/10.1016/j. epsl.2006.09.015

Cowgill, E., Gold, R. D., Chen, X. H., Wang, X. F., Arrowsmith, J. R., \& Southon, J. (2009). Low Quaternary slip rate reconciles geodetic and geologic rates along the Altyn Tagh fault, northwestern Tibet. Geology, 37(7), 647-650. https://doi.org/10.1130/G25623A.1

Daout, S., Jolivet, R., Lasserre, C., Doin, M.-P., Barbot, S., Tapponnier, P., et al. (2016). Along-strike variations of the partitioning of convergence across the Haiyuan fault system detected by InSAR. Geophysical Journal International, 205(1), 536-547. https://doi.org/ 10.1093/gji/ggw028

Dewald, A., Heinze, S., Jolie, J., Zilges, A., Dunai, T., Rethemeyer, J., et al. (2013). CologneAMS, a dedicated center for accelerator mass spectrometry in Germany. Nuclear Instruments \& Methods in Physics Research, Section B (Beam Interactions with Materials and Atoms), $294,18-23$.

England, P., \& Houseman, G. (1986). Finite strain calculations of continental deformation. 2. Comparison with the India-Asia collision zone. Journal of Geophysical Research, 91(B3), 3664-3676. https://doi.org/10.1029/JB091iB03p03664 
England, P., \& McKenzie, D. (1982). A thin viscous sheet model for continental deformation. Geophysical Journal International, 70(2), 295-321. https://doi.org/10.1111/j.1365-246X.1982.tb04969.x

England, P., \& Molnar, P. (2005). Late Quaternary to decadal velocity fields in Asia. Journal of Geophysical Research, 110, B12401. https:// doi.org/10.1029/2004JB003541

Frankel, K. L., Dolan, J. F., Finkel, R. C., Owen, L. A., \& Hoeft, J. S. (2007). Spatial variations in slip rate along the Death Valley-Fish Lake Valley fault system determined from LiDAR topographic data and cosmogenic 10Be geochronology. Geophysical Research Letters, 34, L18303. https://doi.org/10.1029/2007GL030549

Friedrich, A. M., Wernicke, B. P., Niemi, N. A., Bennett, R. A., \& Davis, J. L. (2003). Comparison of geodetic and geologic data from the Wasatch region, Utah, and implications for the spectral character of Earth deformation at periods of 10 to 10 million years. Journal of Geophysical Research, 108(B4), 2199. https://doi.org/10.1029/2001JB000682

Gan, W., Zhang, P., Shen, Z.-K., Niu, Z., Wang, M., Wan, Y., et al. (2007). Present-day crustal motion within the Tibetan Plateau inferred from GPS measurements. Journal of Geophysical Research, 112, B08426. https://doi.org/10.1029/2005JB004120

Gaudemer, Y., Tapponnier, P., Meyer, B., Peltzer, G., Shunmin, G., Zhitai, C., et al. (1995). Partitioning of crustal slip between linked, active faults in the eastern Qilian Shan and evidence for a major seismic gap, the 'Tianzhu gap', on the western Haiyuan Fault, Gansu (China). Geophysical Journal International, 120(3), 599-645. https://doi.org/10.1111/j.1365-246X.1995.tb01842.x

Gold, R. D., Cowgill, E., Arrowsmith, J. R., Chen, X., Sharp, W. D., Cooper, K. M., \& Wang, X. F. (2011). Faulted terrace risers place new constraints on the late Quaternary slip rate for the central Altyn Tagh fault, northwest Tibet. Bulletin, 123(5-6), 958-978. https://doi.org/ 10.1130/B30207.1

Gold, R. D., Cowgill, E., Arrowsmith, J. R., Gosse, J., Chen, X. H., \& Wang, X. F. (2009). Riser diachroneity, lateral erosion, and uncertainty in rates of strike-slip faulting. A case study from Tuzidun along the Altyn Tagh Fault, NW China. Journal of Geophysical Research, 114, B04401. https://doi.org/10.1029/2008JB005913

Grove, K., \& Niemi, T. M. (2005). Grove K, Niemi T M. Late Quaternary deformation and slip rates in the northern San Andreas fault zone at Olema Valley, Marin County, California[J]. Tectonophysics, 401(3-4), 231-250. https://doi.org/10.1016/j.tecto.2005. 03.014

Hancock, G. S., \& Anderson, R. S. (2002). Numerical modeling of fluvial strath-terrace formation in response to oscillating climate. Geological Society of America Bulletin, 114(9), 1131-1142. https://doi.org/10.1130/00167606(2002)114\%3C1131:NMOFST\% 3E2.0.CO;2

He, W. G., Liu, B. C., Lv, T. Y., Yuan, D. Y., Liu, J. S., \& Liu, X. F. (1994). Study on the segmentation of Laohushan fault zone [in Chinese] Northwestern Seismological Journal, 16, 66-72.

Hetzel, R., Küster, Y., Krbetschek, M., \& Tao, M. (2006). Holocene loess sedimentation along the Qilian Shan (China): Significance for understanding the processes and timing of loess deposition. Quaternary Science Reviews, 25(1-2), 114-125. https://doi.org/10.1016/j. quascirev.2005.03.003

Hetzel, R., Tao, M., Stokes, S., Niedermann, S., Ivy-Ochs, S., Gao, B., et al. (2004). Late Pleistocene/Holocene slip rate of the Zhangye thrust (Qilian Shan, China) and implications for the active growth of the northeastern Tibetan Plateau. Tectonics, 23, TC6006. https://doi.org/ $10.1029 / 2004 \mathrm{TC} 001653$

Jiang, W., Han, Z., Guo, P., Zhang, J., Jiao, Q., Kang, S., \& Tian, Y. (2017). Slip rate and recurrence intervals of the east Lenglongling fault constrained by morphotectonics: Tectonic implications for the northeastern Tibetan Plateau. Lithosphere, 9(3), 417-430. https://doi.org/ 10.1130/L597.1

Jolivet, R., Lasserre, C., Doin, M. P., Guillaso, S., Peltzer, G., Dailu, R., et al. (2012). Shallow creep on the Haiyuan fault (Gansu, China) revealed by SAR interferometry. Journal of Geophysical Research, 117, B06401. https://doi.org/10.1029/2011JB008732

Jolivet, R., Lasserre, C., Doin, M. P., Peltzer, G., Avouac, J. P., Sun, J., \& Dailu, R. (2013). Spatio-temporal evolution of aseismic slip along the Haiyuan fault, China. Implications for fault frictional properties. Earth and Planetary Science Letters, 377-378, 23-33. https://doi.org/ 10.1016/j.epsl.2013.07.020

Kirby, E., Harkins, N., Wang, E. Q., Shi, X. H., Fan, C., \& Burbank, D. (2007). Slip rate gradients along the eastern Kunlun fault. Tectonics, 26, TC2010. https://doi.org/10.1029/2006TC002033

Kotz, S. (2004). Multivariate t-Distributions and their Applications. Cambridge, UK: Cambridge University Press.

Lague, D., Hovius, N., \& Davy, P. (2005). Discharge, discharge variability, and the bedrock channel profile. Journal of Geophysical Research, 110, F04006. https://doi.org/10.1029/2004JF000259

Lasserre, C., Gaudemer Y., Tapponnier P., Mériaux A.S., van der Woerd J., Daoyang Y., et al. (2002). Fast late Pleistocene slip rate on the Leng Long Ling segment of the Haiyuan fault, Qinghai, China. Journal of Geophysical Research, 107(B11), 2276. https://doi.org/10.1029/ 2000JB000060

Lasserre, C., Morel, P. H., Gaudemer, Y., Tapponnier, P., Ryerson, F. J., King, G. C. P., et al. (1999). Postglacial left slip rate and past occurrence of $\mathrm{M} \geq 8$ earthquakes on the western Haiyuan fault, Gansu, China. Journal of Geophysical Research, 104(B8), 17,633-17,651. https://doi.org/10.1029/1998JB900082

Le Beon, M., Klinger, Y., Amrat, A. Q., Agnon, A., Dorbath, L., Baer, G., et al. (2008). Slip rate and locking depth from GPS profiles across the southern Dead Sea Transform. Journal of Geophysical Research, 113, B11403. https://doi.org/10.1029/2007JB005280

Le Beon, M., Klinger, Y., Mériaux, A.-S., Al-Qaryouti, M., Finkel, R. C., Mayyas, O., \& Tapponnier, P. (2012). Quaternary morphotectonic mapping of the Wadi Araba and implications for the tectonic activity of the southern Dead Sea Fault. Tectonics, 31, TC5003. https://doi. org/10.1029/2012TC003112

Li, C. Y., Zhang, P. Z., Yin, J. H., \& Min, W. (2009). Late Quaternary left-lateral slip rate of the Haiyuan fault, northeastern margin of the Tibetan Plateau. Tectonics, 28, TC5010. https://doi.org/10.1029/2008TC002302

Li, H. B., van der Woerd, J., Tapponnier, P., Klinger, Y., Qi, X. X., Yang, J. S., \& Zhu, Y. (2005). Slip rate on the Kunlun fault at Hongshui Gou, and recurrence time of great events comparable to the 14/11/2001, Mw 7.9 Kokoxili earthquake. Earth and Planetary Science Letters, 237(1-2), 285-299. https://doi.org/10.1016/j.epsl.2005.05.041

Liu, B. C., Yuan, D. Y., He, W. G., \& Liu, X. F. (1992). The strong earthquake hazard analysis of the western Haiyuan fault zone [in Chinese]. Journal of Seismic Engineering, S1, 49-56.

Liu, J. R., Ren, Z. K., Zhang, H. P., Li, C. Y., Zhang, Z. Q., Zheng, W. J., et al. (2018). Late Quaternary slip rate of the Laohushan fault within the Haiyuan fault zone and its tectonic implications [in Chinese]. Chinese Journal of Geophysics, 61(4), 1281-1297. https://doi.org/ 10.6038/cjg2018L0364

Liu-Zeng, J., Klinger, Y., Xu, X., Lasserre, C., Chen, G., Chen, W., et al. (2007). Millennial recurrence of large earthquakes on the Haiyuan fault near Songshan, Gansu province, china. Bulletin of the Seismological Society of America, 97(1B), 14-34. https://doi.org/10.1785/ 0120050118 
Malatesta, L. C., Avouac, J.-P., Brown, N. D., Breitenbach, S. F. M., Pan, J., Chevalier, M.-L., et al. (2018). Lag and mixing during sediment transfer across the Tian Shan piedmont caused by climate-driven aggradation-incision cycles. Basin Research, 30(4), 613-635. https:// doi.org/10.1111/bre.12267

Meade, B. J. (2007). Present-day kinematics at the India-Asia collision zone. Geology, 35(1), 81. https://doi.org/10.1130/g22924a.1

Meade, B. J., Klinger, Y., \& Hetland, E. A. (2013). Inference of multiple earthquake-cycle relaxation timescales from irregular geodetic sampling of interseismic deformation. Bulletin of the Seismological Society of America, 103(5), 2824-2835. https://doi.org/10.1785/ 0120130006

Mériaux, A. S., Ryerson, F. J., Tapponnier, P., van der Woerd, J., Finkel, R. C., Xu, X., et al. (2004). Rapid slip along the central Altyn Tagh Fault. Morphochronologic evidence from Cherchen He and Sulamu Tagh. Journal of Geophysical Research, 109, B06401. https://doi.org/ 10.1029/2003JB002558

Mériaux, A. S., Tapponnier, P., Ryerson, F. J., Xiwei, X., King, G., van der Woerd, J., et al. (2005). The Aksay segment of the northern Altyn Tagh fault. Tectonic geomorphology, landscape evolution, and Holocene slip rate. Journal of Geophysical Research, 110, B04404. https:// doi.org/10.1029/2004JB003210

Mériaux, A. S., van der Woerd, J., Tapponnier, P., Ryerson, F. J., Finkel, R. C., Lasserre, C., \& Xu, X. (2012). The Pingding segment of the Altyn Tagh Fault $\left(91^{\circ} \mathrm{E}\right)$ : Holocene slip-rate determination from cosmogenic radionuclide dating of offset fluvial terraces. Journal of Geophysical Research, 117, B09406. https://doi.org/10.1029/2012JB009289

Molnar, P., \& Tapponnier, P. (1975). Cenozoic tectonics of Asia: effects of a continental collision. Science, 189(4201), 419-426. https://www. jstor.org/stable/1740465, https://doi.org/10.1126/science.189.4201.419

Ouchi, S. (2004). Flume experiments on the horizontal stream offset by strike-slip faults. Earth Surface Processes and Landforms, 29(2), 161-173. https://doi.org/10.1002/esp.1017

Ouchi, S. (2005). Development of offset channels across the San Andreas Fault. Geomorphology, 70(1-2), 112-128. https://doi.org/10.1016/j. geomorph.2005.04.004

Peltzer, G., \& Saucier, F. (1996). Present-day kinematics of Asia derived from geologic fault rates. Journal of Geophysical Research, 101(B12), 27,943-27,956. https://doi.org/10.1029/96JB02698

Peltzer, G., \& Tapponnier, P. (1988). Formation and evolution of strike-slip faults, rifts, and basins during the India-Asia collision. An experimental approach. Journal of Geophysical Research, 93(B12), 15,085-15,117. https://doi.org/10.1029/JB093iB12p15085

Poisson, B., \& Avouac, J. P. (2004). Holocene hydrological changes inferred from alluvial stream entrenchment in north Tian Shan (northwestern China). The Journal of Geology, 112(2), 231-249. https://doi.org/10.1086/381659

Rittase, W. M., Kirby, E., McDonald, E., Walker, J. D., Gosse, J., Spencer, J. Q. G., \& Herrs, A. J. (2014). Temporal variations in Holocene slip rate along the central Garlock fault, Pilot Knob Valley, California. Lithosphere, 6(1), 48-58. https://doi.org/10.1130/L286.1

Rockwell, T., Lindvall, S., Herzberg, M., Murbach, D., Dawson, T., \& Berger, G. (2000). Paleoseismology of the Johnson Valley, Kickapoo, and Homestead Valley faults. Clustering of earthquakes in the eastern California shear zone. Bulletin of the Seismological Society of America, 90(5), 1200-1236. https://doi.org/10.1785/0119990023

Royden, L. H., Burchfiel, B. C., King, R. W., Wang, E. Q., Chen, Z. L., Shen, F., \& Liu, Y. (1997). Surface deformation and lower crustal flow in eastern Tibet. Science, 276(5313), 788-790. https://doi.org/10.1126/science.276.5313.788

Royden, L. H., Burchfiel, B. C., \& van der Hilst, R. D. (2008). The geological evolution of the Tibetan Plateau. Science, 321(5892), 1054-1058. https://doi.org/10.1126/science.1155371

Siame, L. L., Chen, R. F., Derrieux, F., Lee, J. C., Chang, K. J., Bourlès, D. L., et al. (2012). Pleistocene alluvial deposits dating along frontal thrust of Changhua Fault in western Taiwan. The cosmic ray exposure point of view. Journal of Asian Earth Sciences, 51, 1-20. https:// doi.org/10.1016/j.jseaes.2012.02.002

Stewart, N., Gaudemer, Y., Manighetti, I., Serreau, L., Vincendeau, A., Dominguez, S., et al. (2018). “3D_Fault_Offsets,” a Matlab code to automatically measure lateral and vertical fault offsets in topographic data: Application to San Andreas, Owens Valley, and Hope faults Journal of Geophysical Research: Solid Earth, 123, 815-835. https://doi.org/10.1002/2017JB014863

Stone, J. O. (2000). Air pressure and cosmogenic isotope production. Journal of Geophysical Research, 105(B10), 23,753-23,759. https://doi. org/10.1029/2000JB900181

Stuiver, M., \& Polach, H. A. (1977). Discussion; reporting of ${ }^{14} \mathrm{C}$ data. Radiocarbon, 19, 355-369.

Stuiver, M., \& Reimer, P. J. (1993). Extended ${ }^{14} \mathrm{C}$ data base and revised CALIB $3.0{ }^{14} \mathrm{C}$ age calibration program. Radiocarbon,35, 215-230.

Tapponnier, P., Peltzer, G., \& Armijo, R. (1986). On the mechanics of the collision between India and Asia. Geological Society, London, Special Publications, 19(1), 113-157. https://doi.org/10.1144/GSL.SP.1986.019.01.07

Tapponnier, P., \& Molnar, P. (1977). Active faulting and tectonics in China. Journal of Geophysical Research, 82(20), 2905-2930. https://doi. org/10.1029/JB082i020p02905

Tapponnier, P., Zhiqin, X., Roger, F., Meyer, B., Arnaud, N., Wittlinger, G., \& Jingsui, Y. (2001). Oblique stepwise rise and growth of the Tibet Plateau. Science, 294(5547), 1671-1677. https://doi.org/10.1126/science.105978

Thatcher, W. (2007). Microplate model for the present-day deformation of Tibet. Journal of Geophysical Research, 112, B01401. https://doi. org/10.1029/2005JB004244

Toké, N. A., Arrowsmith, J. R., Rymer, M. J., Landgraf, A., Haddad, D. E., Busch, M., et al. (2011). Late Holocene slip rate of the San Andreas Fault and its accommodation by creep and moderate-magnitude earthquakes at Parkfield, California. Geology, 39(3), 243-246. https://doi.org/10.1130/G31498.1

US Geological Survey National Earthquake Information Center (2000). Retrieved https://earthquake.usgs.gov/earthquakes/eventpage/ usp0009u46/executive

van der Woerd, J., Klinger, Y., Sieh, K., Tapponnier, P., Ryerson, F. J., \& Mériaux, A.-S. (2006). Long-term slip rate of the southern San Andreas Fault from ${ }^{10} \mathrm{Be}-{ }^{26} \mathrm{Al}$ surface exposure dating of an offset alluvial fan. Journal of Geophysical Research, 111, B04407. https://doi org/10.1029/2004JB003559

van der Woerd, J., Ryerson, F., Tapponnier, P., Gaudemer, Y., Finkel, R., Mériaux, A.-S., et al. (1998). Holocene left-slip rate determined by cosmogenic surface dating on the Xidatan segment of the Kunlun fault (Qinghai, China). Geology, 26(8), 695-698. https://doi.org/ 10.1130/0091-7613(1998)026<0695:HLSRDB>2.3.CO;2

van der Woerd, J., Tapponnier, P., Ryerson, F. J., Meriaux, A. S., Meyer, B., Gaudemer, Y., et al. (2002). Uniform postglacial slip-rate along the central $600 \mathrm{~km}$ of the Kunlun Fault (Tibet), from ${ }^{26} \mathrm{Al},{ }^{10} \mathrm{Be}$, and ${ }^{14} \mathrm{C}$ dating of riser offsets, and climatic origin of the regional morphology. Geophysical Journal International, 148(3), 356-388. https://doi.org/10.1046/j.1365-246x.2002.01556.x

von Blanckenburg, F., Hewawasam, T., \& Kubik, P. W. (2004). Cosmogenic nuclide evidence for low weathering and denudation in the wet, tropical highlands of Sri Lanka. Journal of Geophysical Research, 109, F03008. https://doi.org/10.1029/2003JF000049 
Wang, W., Qiao, X., Yang, S., \& Wang, D. (2017). Present-day velocity field and block kinematics of Tibetan Plateau from GPS measurements. Geophysical Journal International, 208(2), 1088-1102. https://doi.org/10.1093/gji/ggw445

Wechsler, N., Rockwell, T. K., \& Klinger, Y. (2017). Variable slip-rate and slip-per-event on a plate boundary fault: The Dead Sea fault in northern Israel. Tectonophysics, 722, 210-226. https://doi.org/10.1016/j.tecto.2017.10.017

Weldon, R. J., \& Sieh, K. E. (1985). Holocene rate of slip and tentative recurrence interval for large earthquakes on the San Andreas fault, Cajon Pass, Southern California. Geological Society of America Bulletin, 96(6), 793-812. https://doi.org/10.1130/0016-7606(1985)96<793: HROSAT $>2.0 . \mathrm{CO} ; 2$

Wright, T. J., Parsons, B., England, P. C., \& Fielding, E. J. (2004). InSAR observations of low slip rates on the major faults of western Tibet. Science, 305(5681), 236-239. https://doi.org/10.1126/science.1096388

Xu, X., Wang, F., Zheng, R., Chen, W., Ma, W., Yu, G., et al. (2005). Late Quaternary sinistral slip rate along the Altyn Tagh fault and its structural transformation model. Science in China Series D: Earth Sciences, 48(3), 384. https://doi.org/10.1360/02yd0436

Yang, H. B., Yang, X. S., Huang, X. N., Li, A., Huang, W. L., \& Zhang, L. (2018). New constraints on slip rates of the Fodongmiao-Hongyazi fault in the Northern Qilian Shan, NE Tibet, from the ${ }^{10}$ Be exposure dating of offset terraces. Journal of Asian Earth Sciences, 151, 131-147. https://doi.org/10.1016/j.jseaes.2017.10.034

Yokoyama, R., Shirasawa, M., \& Pike, R. J. (2002). Visualizing topography by openness. A new application of image processing to digital elevation models. Photogrammetric Engineering and Remote Sensing, 68(3), 257-266.

Yuan, D. Y., Liu, B. C., Lv, T. Y., He, W. G., Liu, X. F., \& Gan, W. J. (1998). Study on the segmentation in east segment of the northern Qilianshan fault zone [in Chinese]. Northwestern Seismological Journal, 20, 27-34.

Zhang, J., Nottebaum, V., Tsukamoto, S., Lehmkuhl, F., \& Frechen, M. (2015). Late Pleistocene and Holocene loess sedimentation in central and western Qilian Shan (China) revealed by OSL dating. Quaternary International, 372, 120-129. https://doi.org/10.1016/j. quaint.2014.12.054

Zhang, P., Molnar, P., Burchfiel, B. C., Royden, L., Yipeng, W., Qidong, D., et al. (1988). Bounds on the Holocene slip rate of the Haiyuan fault, north-central China. Quaternary Research, 30(02), 151-164. https://doi.org/10.1016/0033-5894(88)90020-8

Zhang, P. Z., Molnar, P., \& Xu, X. (2007). Late Quaternary and present-day rates of slip along the Altyn Tagh Fault, northern margin of the Tibetan Plateau. Tectonics, 26, TC5010. https://doi.org/10.1029/2006TC002014

Zhang, P. Z., Shen, Z. K., Wang, M., Gan, W. J., Burgmann, R., \& Molnar, P. (2004). Continuous deformation of the Tibetan Plateau from global positioning system data. Geology, 32(9), 809-812. https://doi.org/10.1130/G20554.1 